Biogeosciences, 10, 871-889, 2013

www.biogeosciences.net/10/871/2013/

doi:10.5194/bg-10-871-2013

(C) Author(s) 2013. CC Attribution 3.0 License.

\title{
Isoprene emissions from a tundra ecosystem
}

\author{
M. J. Potosnak ${ }^{1}$, B. M. Baker ${ }^{2}$, L. LeStourgeon ${ }^{1}$, S. M. Disher ${ }^{2}$, K. L. Griffin ${ }^{3}$, M. S. Bret-Harte ${ }^{4}$, and G. Starr ${ }^{5}$ \\ ${ }^{1}$ Department of Environmental Science and Studies, DePaul University, Chicago, Illinois, USA \\ ${ }^{2}$ Department of Chemistry, California State University-Sacramento, Sacramento, California, USA \\ ${ }^{3}$ Lamont-Doherty Earth Observatory of Columbia University, Palisades, New York, USA \\ ${ }^{4}$ Institute of Arctic Biology, University of Alaska-Fairbanks, Fairbanks, Alaska, USA \\ ${ }^{5}$ Department of Biological Sciences, University of Alabama, Tuscaloosa, Alabama, USA
}

Correspondence to: M. J. Potosnak (mpotosna@ depaul.edu)

Received: 7 September 2012 - Published in Biogeosciences Discuss.: 1 October 2012

Revised: 7 January 2013 - Accepted: 10 January 2013 - Published: 7 February 2013

\begin{abstract}
Whole-system fluxes of isoprene from a moist acidic tundra ecosystem and leaf-level emission rates of isoprene from a common species (Salix pulchra) in that same ecosystem were measured during three separate field campaigns. The field campaigns were conducted during the summers of 2005, 2010 and 2011 and took place at the Toolik Field Station $\left(68.6^{\circ} \mathrm{N}, 149.6^{\circ} \mathrm{W}\right)$ on the north slope of the Brooks Range in Alaska, USA. The maximum rate of whole-system isoprene flux measured was over $1.2 \mathrm{mg} \mathrm{C} \mathrm{m}^{-2} \mathrm{~h}^{-1}$ with an air temperature of $22^{\circ} \mathrm{C}$ and a PAR level over $1500 \mu \mathrm{mol} \mathrm{m} \mathrm{m}^{-2} \mathrm{~s}^{-1}$. Leaf-level isoprene emission rates for $S$. pulchra averaged $12.4 \mathrm{nmol} \mathrm{m}^{-2} \mathrm{~s}^{-1}$ $\left(27.4 \mu \mathrm{g} \mathrm{Cgdw}^{-1} \mathrm{~h}^{-1}\right)$ extrapolated to standard conditions $\left(\operatorname{PAR}=1000 \mu \mathrm{mol} \mathrm{m}^{-2} \mathrm{~s}^{-1}\right.$ and leaf temperature $\left.=30^{\circ} \mathrm{C}\right)$. Leaf-level isoprene emission rates were well characterized by the Guenther algorithm for temperature with published coefficients, but less so for light. Chamber measurements from a nearby moist acidic tundra ecosystem with little $S$. pulchra emitted significant amounts of isoprene, but at lower rates $\left(0.45 \mathrm{mg} \mathrm{C} \mathrm{m}^{-2} \mathrm{~h}^{-1}\right)$ suggesting other significant isoprene emitters. Comparison of our results to predictions from a global model found broad agreement, but a detailed analysis revealed some significant discrepancies. An atmospheric chemistry box model predicts that the observed isoprene emissions have a significant impact on Arctic atmospheric chemistry, including a reduction of hydroxyl radical $(\mathrm{OH})$ concentrations. Our results support the prediction that isoprene emissions from Arctic ecosystems will increase with global climate change.
\end{abstract}

\section{Introduction}

Emission of biogenic volatile organic compounds (BVOCs) from plants strongly couples terrestrial ecosystem processes and atmospheric chemistry cycles, and the cross-disciplinary nature of this subject brings together the fields of ecophysiology, plant physiology, ecology, micrometeorology, and atmospheric chemistry (Harrison et al., 2013). While the functions of some BVOCs are now well understood - ranging from protection against herbivory (monoterpenes; Trapp and Croteau, 2001) to by-products of plant growth (methanol; Fall, 2003) - the function of another important BVOC, isoprene, is still debated (Sharkey and Singsaas, 1995; Rosenstiel et al., 2004; Loreto et al., 2001; Sharkey et al., 2008). This study focuses on isoprene $\left(\mathrm{C}_{5} \mathrm{H}_{8}\right)$, which accounts for 500 to $750 \mathrm{Tg}$ of carbon emitted globally per year (Guenther et al., 2006).

Once isoprene enters the atmosphere, it has profound effects on regional air quality (Chameides et al., 1988), the global oxidizing capacity of the atmosphere (Crutzen and Zimmermann, 1991), and secondary organic aerosol production (Andreae and Crutzen, 1997). Isoprene emissions are modelled using algorithms derived from the leaf-level response of emissions to variations in temperature and light, which have mechanistic underpinnings (Guenther et al., 1993; Grote and Niinemets, 2008; Monson et al., 2012). Isoprene emissions are also sensitive to climate change (Lathiere et al., 2010; Peñuelas and Staudt, 2010; Arneth et al., 2011; Laothawornkitkul et al., 2009). Examples of factors affected by climate change which impact ecosystem isoprene production are species composition (Sharkey and Yeh, 2001); 
temperature (Monson and Fall, 1989; Sharkey et al., 1999); nitrogen availability (Harley et al., 1994); herbivory/insect interactions (McCormick et al., 2012; Yuan et al., 2009); air quality (Pinto et al., 2010); stress and multiple stressors (Holopainen and Gershenzon, 2010; Niinemets, 2010); and canopy architecture (Harley et al., 1996; Baldocchi et al., 1999).

Most field studies of isoprene emissions have focused on temperate ecosystems (e.g., Goldstein et al., 1995; Pressley et al., 2005; McKinney et al., 2011) due to accessibility and tropical ecosystems (e.g., Geron et al., 2002; Rinne et al., 2002; Langford et al., 2010) because warm temperatures, high biomass densities, and long growing seasons drive globally significant fluxes. Other studies have stretched from savannahs (e.g., Guenther et al., 1996; Otter et al., 2003) to boreal forests (e.g., Rinne et al., 2000; Spirig et al., 2004). However, Arctic (latitude above $66.6^{\circ} \mathrm{N}$ ) tundra ecosystems have been neglected, with most studies coming from the same field station near Abisko, Sweden (Ekberg et al., 2009; Faubert et al., 2010; Rinnan et al., 2011; Tiiva et al., 2008; Ekberg et al., 2011; Holst et al., 2010; Faubert et al., 2012; note that no isoprene emissions were detected in the Faubert et al., 2012 study) and another study in northern Finland (Tiiva et al., 2007).

The Arctic is an important region to observe ecosystem responses to global climate change. Observations and model predictions both indicate that high-latitude ecosystems are particularly sensitive to global climate change for two reasons. First, the climate of the Arctic is disproportionately affected by global climate change. For example, $\mathrm{CO}_{2}$ concentration measurements have revealed increases in growing-season length (Myneni et al., 1997), and temperature records (including paleoclimate proxies) have revealed a strong warming trend at high latitudes (Overpeck et al., 1997; Serreze et al., 2000). Precipitation amounts also have increased during the last 50 years (Rawlins et al., 2010). Unique aspects of the Arctic climate system also contribute to increased sensitivity to climate change. The recent precipitous decline in sea ice extent (Kwok et al., 2009) also highlights the sensitivity of the Arctic region to global change. Changes in surface temperature, ice sheets, glaciers, snow cover, permafrost, and sea ice are detectable through satellite observations (Comiso and Parkinson, 2004). Additionally, many climate models predict a decrease in thermohaline circulation, which impacts the heat budget of vast regions of the Arctic (Clark et al., 2002). Finally, Arctic warming trends drastically change the state of an ecosystem by eroding the permafrost layer and increasing active layer depth (Chen et al., 2003; Frauenfeld et al., 2004).

The second reason driving the sensitivity of the region to global climate change is that Arctic ecosystems are highly adapted to extreme environmental conditions and small environmental changes may have large consequences. For example, if a perturbation in Arctic climate causes an increase in deciduous shrubs, the "snow fence" effect will cause greater snow depths leading to warmer soil temperatures, increased mineralization rates, and more nutrient availability - which favours further shrub growth (Sturm et al., 2001). This positive feedback loop demonstrates the inherent instability of the tundra ecosystem in regard to climate change.

\subsection{Previous research on Arctic air-surface exchanges}

Previous field studies have explored aspects of the impact of surface exchanges with the terrestrial biosphere on atmospheric chemistry in high-latitude regions, but there has been little focus on summer-time BVOC chemistry. The Arctic Boundary Layer Expedition (ABLE-3A) focused on investigating exchange processes of $\mathrm{NO}_{\mathrm{y}}, \mathrm{CO}$, and methane on the ground in the Yukon-Kuskokwim Delta region. These ground-based experiments were complemented by airborne measurements of a variety of important reactive trace gases (Harriss et al., 1992b). While detailed knowledge of methane sources and sinks (Bartlett et al., 1992) as well as $\mathrm{NO}_{\mathrm{x}}$ (Bakwin et al., 1992) and $\mathrm{O}_{3}$ deposition fluxes (Jacob et al., 1992) were obtained during ABLE-3A, BVOC exchange measurements were not quantified. Non-methane hydrocarbon measurements on the NASA Electra research aircraft, however, indicated the abundance of important biogenic reactive trace gases in the Arctic (isoprene, Blake et al., 1992).

In contrast to the terrestrial biosphere, many studies have focused on the impact of ice and snow surfaces on Arctic atmospheric chemistry. These studies were motivated by the observation that these air-surface exchanges had important implications for cycles of atmospheric chemistry in the Arctic. One emphasis has been springtime tropospheric $\mathrm{O}_{3}$ depletion events (Barrie et al., 1988), which are observed throughout the Arctic at coastal stations (Helmig et al., 2007). Arctic tropospheric $\mathrm{O}_{3}$ depletion is thought to be linked to emissions of halogens from within the sea ice zone (Helmig et al., 2007). In addition, a significant amount of data has been collected above the snowpack and firm ice with important implications for Arctic photochemistry. These investigations were prompted by the finding from the Polar Sunrise Experiment (PSE98) that formaldehyde was emitted from the snowpack at Alert after polar sunrise (Sumner and Shepson, 1999; Sumner et al., 2002). The impact of air-ice exchanges on Arctic atmospheric chemistry demonstrates the sensitivity of the system to relatively small exchanges of reactive species.

\subsection{Previous research on global change factors and deciduous shrub species}

The Toolik Field Station (TFS) has been the setting for a wide variety of ecological experiments focused on global change factors in the Arctic. The shrub species in the moist acidic tundra ecosystems near Toolik are dominated by two genera: Betula (birch) and Salix (willow) (Kade et al., 2012). Betula spp. are not isoprene emitters, although they do emit other 
BVOCs, while Salix spp. are strong isoprene emitters (Wiedinmyer, 2004) and are the focus of this study. Most of the global change experiments conducted at TFS fall into four categories: fertilization, warming, shading, and alteration in growing season length (including interactions among these factors). Shaver et al. (2001) found that Betula nana, a deciduous species (dwarf birch), dominated the upper canopy when nutrients were added to a moist acidic tundra ecosystem. The fertilization effect can become self-sustaining since leaf litter from $B$. nana is more readily decomposable (van Wijk et al., 2004). In comparison, for sites where deciduous species had a relatively low starting percentage of cover (i.e., moist non-acidic tundra), deciduous shrub cover did not increase with either fertilization or warming (Gough and Hobbie, 2003). Other studies have focused more generally on the total impact on shrub cover. Warming experiments showed species responses that favoured deciduous plants (Hobbie and Chapin, 1998) in moist acidic tussock tundra, while shading experiments led to decreased shrub growth (Chapin et al., 1995). Another snow-depth study found that either increased soil temperatures (due to direct warming) or drifting snow lead to increases in growing season length and greater biomass (Walker et al., 1999) for both moist and dry ecosystem types. This predicted increase in the dominance of shrubs has been seen in aerial photographs (Tape et al., 2006), detected in the Russian Arctic using tree-ring growth (Forbes et al., 2010) and is the current focus of remote sensing studies (e.g., Boelman et al., 2011).

Changing species-composition effects on ecosystem BVOC emissions in the Arctic are complex. A study of mountain birch (B. pubescens) forests found that ecosystem BVOC emissions (in particular, sesquiterpenes) would decrease because warming would increase nutrient availability that would in turn promote ground-cover species with lower emission capacities (Faubert et al., 2012). But increases in deciduous shrubs could lead to increases in ecosystem BVOC emissions. While Betula species are not isoprene emitters, they do emit monoterpenes and sesquiterpenes (Haapanala et al., 2009; Tarvainen et al., 2007), so increases in Betula species would lead to increases in ecosystem BVOC emissions, assuming that the replaced grasses and sedges had lower emission capacities.

\subsection{Current study}

The current study investigates two hypotheses. The first is that isoprene emissions from tundra ecosystems have a significant impact on Arctic atmospheric chemistry. As outlined above, previous Arctic atmospheric chemistry studies show the system is sensitive to air-surface interactions over snow and seawater. Our studies use leaf-level and whole-system measurements of isoprene emission from a moist acidic tundra ecosystem to estimate ecosystem emission factors. First, we compare these measured factors to a global isoprene model. Next, these factors are then used to drive an atmo- spheric chemistry model to determine their impact on Arctic photochemistry. Our second hypothesis is that global change factors will lead to increased isoprene emissions. If isoprene emissions from deciduous shrubs play a key role in the current system, this influence is predicted to grow with the increasing dominance of tundra shrubs from warming Arctic temperatures. We test this hypothesis by performing leaflevel isoprene emission rate measurements at an existing experiment that manipulates nutrients and ecosystem temperature. To support the exploration of these hypotheses we tested the applicability for Arctic tundra species and ecosystems of leaf-level and whole-system models of isoprene emission that were primarily developed based on observations from mid-latitude species.

\section{Methods}

\subsection{Overview of field campaigns}

All research was performed near the Toolik Field Station $\left(68^{\circ} 38^{\prime} \mathrm{N}, 149^{\circ} 38^{\prime} \mathrm{W}\right)$ on the north slope of the Brooks Range in Alaska (Fig. 1) in moist acidic tundra ecosystems. Data were collected during 3 field campaigns that occurred near the peak of the growing season in late June and early July for the years 2005, 2010 and 2011. The eddy covariance technique was used during 2005 and 2010 (denoted as EC05 and EC10) to measure isoprene fluxes at an existing station that measures carbon dioxide $\left(\mathrm{CO}_{2}\right)$ flux. This station is located in the Imnavait Creek experimental watershed, which is $12 \mathrm{~km}$ east of the main field station (labelled EC in Fig. 1), and is at an elevation of $930 \mathrm{~m}$. The existing eddy flux system is part of the Arctic Observatory Network (AON http://aon.iab.uaf.edu, Euskirchen et al., 2012). Whole-system measurements of isoprene fluxes were also obtained with static and dynamic chamber systems during 2011 (CH11) at a location approximately $500 \mathrm{~m}$ north of the main field station (labelled CH in Fig. 1). The leaf-level data were also collected during the 2011 field campaign from and near an existing global change manipulation experiment (labelled LL in Fig. 1).

\subsection{Leaf-level measurements}

Leaf-level measurements were performed with a LI-6400 leaf-gas exchange system (LI-COR Biosciences, Lincoln, Nebraska, USA) with a self-contained LED light source and typical gas-exchange parameters were measured (e.g., photosynthesis, transpiration, conductance and intercellular $\mathrm{CO}_{2}$ concentration). The system has the ability to control leaf temperature, incident light and $\mathrm{CO}_{2}$ concentration of the incoming air stream. There is some ability to control water vapour via a desiccant scrub (Drierite, W. A. Hammond Drierite, Xenia, Ohio, USA) or by adding $<10 \mathrm{~mL}$ of water to the $\mathrm{CO}_{2}$ scrub (soda lime). Incoming air first was drawn though an external filter to remove hydrocarbons and ozone (Refillable 


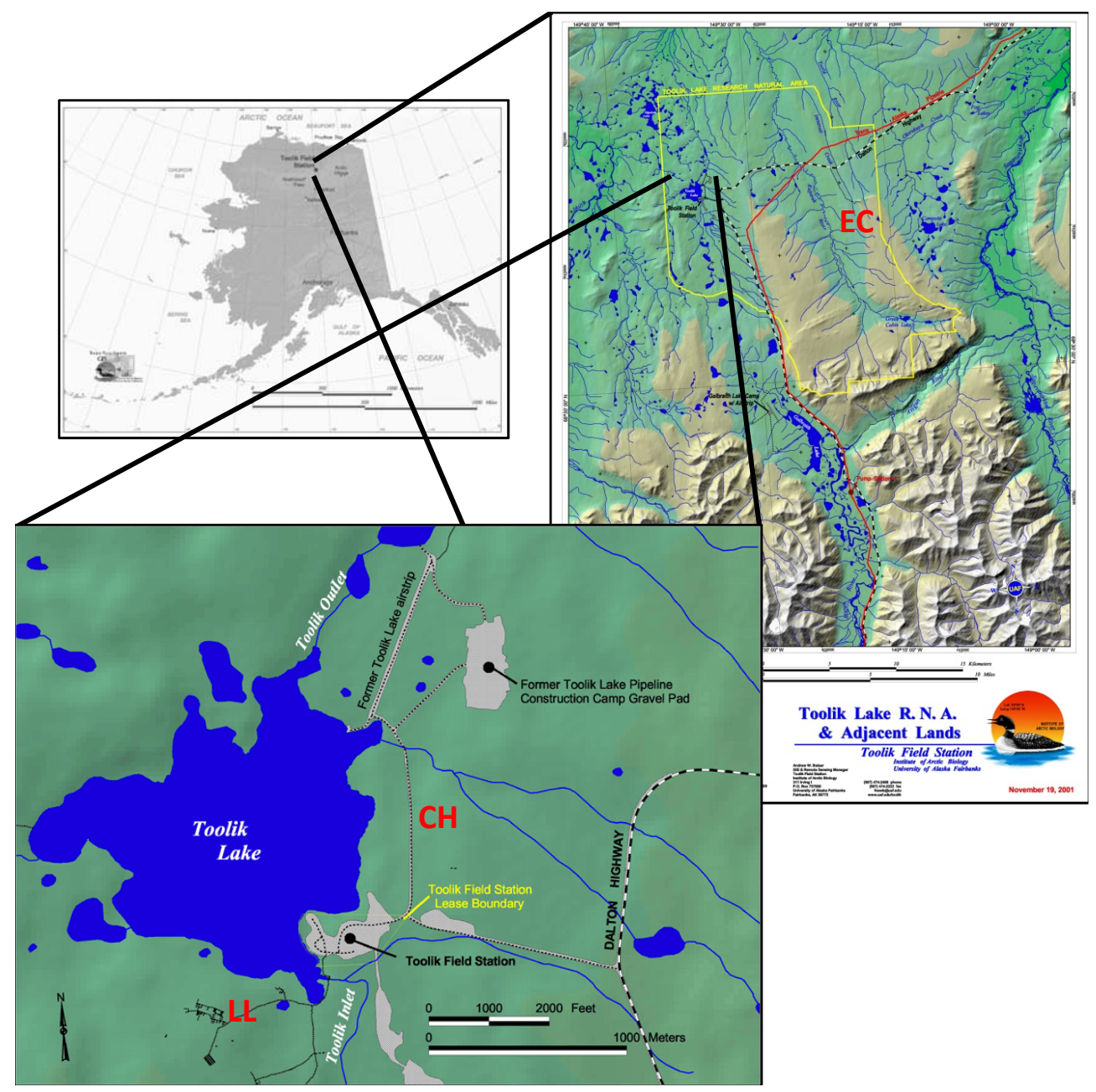

Fig. 1. The Toolik Field Station is located on the north slope of the Brooks Range. The Imnavait Creek experimental watershed (marked EC) is $12 \mathrm{~km}$ east of the main field station, and is at an elevation of $930 \mathrm{~m}$. The chamber measurements were located just north of the field station (marked CH). Leaf-level measurements were performed to the southwest of the station (marked LL). (Map courtesy of the Toolik Field Station GIS Office, http://toolik.alaska.edu/gis/maps/index.php).

Hydrocarbon Trap, Restek, Bellefonte, PA). The impact of isoprene reacting with $\mathrm{O}_{3}$ is minimal because the LI-6400 pump removes most incoming $\mathrm{O}_{3}$ (Geron et al., 2006) and ambient $\mathrm{O}_{3}$ concentrations are low. If $\mathrm{CO}_{2}$ was being controlled, the built-in $\mathrm{CO}_{2}$ scrubber removed all incoming $\mathrm{CO}_{2}$ and the LI-6400 mixer set the concentration using disposable $\mathrm{CO}_{2}$ cartridges (LI-COR).

Isoprene emission rates were determined by measuring the isoprene concentration of air exiting the LI-6400. The exhaust stream was coupled to an automated GC-FID with a fixed solid absorbent trap, and further analytical details are available in the Supplement. All measurements were made on excised leaves in the laboratory. Investigators have done experiments (photosynthesis with B. nana, personal communication, Marjan van de Weg, and respiration with $S$. pulchra, Griffin, data not shown) on excised leaves from this tundra ecosystem, and comparisons have shown no effect of excision on $\mathrm{CO}_{2}$ gas exchange at times up to $2 \mathrm{~h}$. In addition, a comparison of excised leaves and intact leaves conducted at Imnavait Creek showed no significant difference in emission rates $(n=3$, mean cut/uncut ratio 0.88 , standard error $=0.19$ ). We assume the small impact of leaf excision on leaf physiology is due to the relatively low water stress of tundra plants, since leaf water potential has been observed to become less negative at higher latitudes (Figueroa et al., 2010).

Temperature and light curves were obtained by using an autoprogram with a 20 -min time step. For temperature curves, leaf temperature was first set to $30^{\circ} \mathrm{C}$, and then stepped from 20 to 32.5 in $2.5^{\circ} \mathrm{C}$ increments. Although air temperatures were generally lower than this range, leaf temperatures can be elevated by $7^{\circ} \mathrm{C}$ above ambient air temperature in Arctic plants (Wilson, 1957). For light curves, PAR (photosynthetically active radiation) was initially set 
to $1000 \mu \mathrm{mol} \mathrm{m}{ }^{-2} \mathrm{~s}^{-1}$, and then stepped through 100,200 , $400,800,1000$ and $1600 \mu \mathrm{mol} \mathrm{m}^{-2} \mathrm{~s}^{-1}$. For the temperature curves, light was kept constant at $1000 \mu \mathrm{mol} \mathrm{m}^{-2} \mathrm{~s}^{-1}$ and for the light curves, leaf temperature was kept at $25^{\circ} \mathrm{C}$. For all measurements, flow rate was constant at $250 \mu \mathrm{mol} \mathrm{s}^{-1}$ and incoming $\mathrm{CO}_{2}$ was controlled at 400 ppmv. When ambient humidity was low, drops $(<10 \mathrm{~mL})$ of distilled water were added to the $\mathrm{CO}_{2}$ scrub to minimize the leaf vapour pressure deficit.

\subsection{Leaf-level modelling}

The measured leaf-level responses were compared to predictions based on the algorithms proposed by Guenther et al. (1993), commonly known as the Guenther algorithms. These equations are derived from empirical observations but agree well with theoretical considerations, if an adjustment is included to correct a mismatch in the units (Monson et al., 2012). Leaf-level emissions are predicted by

Emission $_{\text {leaf }}=\mathrm{EF}_{\text {leaf }} \times C_{L} \times C_{T}$,

where $\mathrm{EF}_{\text {leaf }}$ is the basal emission rate at $30^{\circ} \mathrm{C}$ leaf temperature and $1000 \mu \mathrm{mol} \mathrm{m}^{-2} \mathrm{~s}^{-1}$ PAR. The two factors are

$C_{L}=\frac{\alpha C_{L 1} L}{\sqrt{1+\alpha^{2} L^{2}}}$,

where $\alpha=0.0027, C_{L 1}=1.066$, and $L$ is the PAR level, and

$C_{T}=\frac{\exp \frac{C_{T 1}\left(T-T_{S}\right)}{\mathrm{RT}_{S} T}}{1+\exp \frac{C_{T 2}\left(T-T_{M}\right)}{\mathrm{RT}_{S} T}}$,

where $\quad R=8.314 \mathrm{~J} \mathrm{~K}^{-1} \mathrm{~mol}^{-1}, \quad C_{T 1}=95000 \mathrm{~J} \mathrm{~mol}^{-1}$, $C_{T 2}=230000 \mathrm{~J} \mathrm{~mol}^{-1}, T_{S}=303 \mathrm{~K}, T_{M}=314 \mathrm{~K}$, and $T$ is the leaf temperature in $\mathrm{K}$.

For light curves, the measured emissions in each curve were normalized by the measurement taken at $\mathrm{PAR}=1000 \mu \mathrm{mol} \mathrm{m} \mathrm{m}^{-2} \mathrm{~s}^{-1}$. To further explore the applicability of the Guenther algorithms to emissions from Artic plants, an additional fit to the leaf-level data was performed which estimated $\alpha$ and $C_{L 1}$ with a non-linear, least-squares technique. For temperature curves, the instrument was not always able to obtain the leaf temperature set point, so measurements were normalized by calculating the slope of a linear fit of measured emissions versus calculated $C_{T}$ values. The slope was then used to normalize the measurements.

\subsection{Global change experiment}

We performed leaf-level isoprene emission rate measurements on S. pulchra plants from an existing global change manipulation experiment (for full details, see Chapin et al., 1995; Bret-Harte et al., 2001; Shaver et al., 2001). The following treatments were applied in addition to the control (C): nitrogen $(\mathrm{N})$, phosphorus $(\mathrm{P})$, combined nitrogen and phosphorus (NP), and a greenhouse $(\mathrm{GH})$ treatment which elevated ecosystem temperature. Each treatment was applied to a 5 by $20 \mathrm{~m}$ plot and replicated in 4 blocks with 3 leaves sampled per block. The fertilization plots $(\mathrm{N}, \mathrm{P}, \mathrm{NP})$ received the respective treatments of fertilizer after snowmelt each June. The greenhouses were simple wooden "A" frames, approximately 2 by $4 \mathrm{~m}$ and are covered annually with $0.15 \mathrm{~mm}$ transparent plastic sheeting in late May and uncovered at the end of August (Bret-Harte et al., 2001). PAR was reduced in the greenhouse due to the plastic sheeting by about $20 \%$ of the ambient light PAR values (data not shown). Air temperature and relative humidity were also measured during the growing season with sensors read every minute and averaged every hour. During the summer months, the daytime air temperature within the greenhouses typically ranged 5$10^{\circ} \mathrm{C}$ warmer than the ambient air temperatures. The data were analysed by first computing a mean from the 3 samples within each block, and then performing an ANOVA on the linear model with the 5 treatments $(n=4)$. The results were also analysed using Tukey's Honest Significant Difference (HSD) test.

\subsection{Eddy covariance measurements}

For EC05 and EC10, we used the eddy covariance (EC) technique to measure ecosystem fluxes. The eddy covariance technique requires that the landscape is homogeneous (Baldocchi, 2003), and the long-term record of $\mathrm{CO}_{2}$ fluxes, including turbulence data, is useful for testing this assumption. $\mathrm{CO}_{2}$ fluxes obtained at this site were well described by an ecosystem model using an ensemble Kalman filter (Rastetter et al., 2010). Ecosystem fluxes were calculated with standard micrometeorological procedures closely related to basic protocols used for analysing eddy covariance data developed by the flux community for the EUROFLUX (now known as CARBOEUROPE) (Aubinet et al., 2000) and AmeriFlux networks (Baldocchi et al., 2001). Wind and isoprene concentration measurements were recorded at a rate 10 and $1 \mathrm{~Hz}$, respectively. Isoprene fluxes were determined directly by using a Fast Isoprene System (FIS) analyser (Guenther and Hills, 1998) from Hills Scientific (Boulder, Colorado, USA). This instrument uses a chemiluminescence technique to measure isoprene by counting photons from the reaction of $\mathrm{O}_{3}$ (generated by the system) and isoprene. Isoprene flux measurements were conducted at the existing $\mathrm{CO}_{2} / \mathrm{H}_{2} \mathrm{O}$ eddy covariance tower. The AON project provided all ancillary measurements (e.g., radiation, air temperature) necessary for interpreting our isoprene flux measurements.

A description of the eddy covariance equipment and data analysis procedures for the $\mathrm{CO}_{2}$ and $\mathrm{H}_{2} \mathrm{O}$ fluxes is given in Rastetter et al. (2010) and is briefly summarized here. Eddy covariance data were collected with an open-path $\mathrm{CO}_{2} / \mathrm{H}_{2} \mathrm{O}$ gas analyser (LI-7500, LI-COR) and sonic anemometer (CSAT3, Campbell Scientific, Logan, Utah, USA) located 
approximately $2 \mathrm{~m}$ above the land surface. The vertical wind was rotated using the 2-D method of Wilczak et al. (2001) and the derived rotation angles closely matched the slope (cf. Turnipseed et al., 2003, Fig. 7). After computing the covariance between the rotated wind and the $\mathrm{CO}_{2}$ concentrations, the $\mathrm{CO}_{2}$ fluxes were corrected using the sensible and latent heat fluxes (Webb et al., 1980). Isoprene fluxes were calculated in a similar manner with two exceptions. First, the FIS instrumental noise restricted the collection frequency to $1 \mathrm{~Hz}$, so the wind measurements were averaged to that frequency. Second, because of relatively low isoprene concentrations, the corrections of Webb et al. (1980) are small and were neglected.

Although the existing flux tower was powered by solar panels and a wind turbine, because of power requirements the FIS was run using a portable gasoline generator ( $2 \mathrm{kVA})$. For EC05, the generator was located approximately $100 \mathrm{~m}$ from the tower, in the prevailing down-wind direction. For EC10, the generator was located approximately $300 \mathrm{~m}$ down slope (towards the west). This allowed for our isoprene measurements to be conducted without contamination of the flux field.

\subsection{Whole-system emission models}

Whole-system isoprene emissions were modelled with two methods. First, for the chamber measurements and for the eddy covariance data, a big-leaf model analogous to Eq. (1) was used:

Emission $_{\text {canopy }}=\mathrm{EF}_{\text {canopy }} \times C_{L} \times C_{T}$.

The only change compared to Eq. (1) is that air temperature was used in place of leaf temperature, which has been assumed before in the literature for a high-latitude ecosystem (Olofsson et al., 2005).

Equation (4) was used to infer the canopy emission factor from the whole-system measurements. Equation 4 was rearranged to solve for $\mathrm{EF}_{\text {canopy }}$ based on the measured values

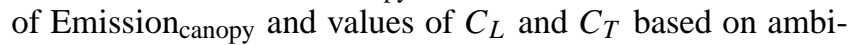
ent light and temperature for each 30-min flux period. The approach uses several assumptions to allow the use of these leaf-level equations. First, air temperature is used in place of the leaf temperature. Second, the canopy is treated as a single flat leaf with a leaf area index (LAI) equal to 1. By plotting observed emissions against the combined temperature and light scaling factors, the canopy emission factor is derived from the slope of the best fit line with a zero intercept. We also employed the MEGAN framework (Model of Emissions of Gases and Aerosols from Nature) described in Guenther et al. (2006). The model employs a radiative transfer scheme to predict incident light for both sun and shade leaves with a 5-layer canopy. In addition, the model calculates leaf temperature accounting for air temperature, vapour pressure deficit and wind speed (Guenther et al., 1999). Although MEGAN has algorithms to account for the impact of
10 and 1-day previous temperature and light regimes on the capony emission factor, those algorithms were not utilised in the analyses for this study. The model uses the following meteorological variables from the existing eddy flux system: solar radiation, air temperature, absolute humidity and wind speed. The only other parameters necessary for MEGAN are LAI of the entire ecosystem, which was set to 0.66 following the work of Williams et al. (2006) at this same field site, latitude $\left(68.5^{\circ} \mathrm{N}\right)$ and canopy type (grass). The MEGAN approach is similar to Eq. (4):

Emission $_{\text {canopy }}=[\varepsilon][\gamma]$,

where $\varepsilon$ is a canopy emission factor analogous to $\mathrm{EF}_{\text {canopy }}$ in Eq. (4) and $\gamma$ depends on the meteorological variables.

We used a transect method to estimate the ecosystem LAI for S. pulchra surrounding the tower, the focus of our leaflevel measurements. Starting $10 \mathrm{~m}$ from the base of the tower, we used existing transects that followed the 4 cardinal directions. Each transect ranged from 10 to $45 \mathrm{~m}$ and each point in the transect was spaced at $5 \mathrm{~m}$. For each point in the transect, we counted the number of branches of S. pulchra within a $30 \mathrm{~cm}$ radius. A random sub-sample of branches was collected and leaf area per branch was determined with a flatbed scanner. The average leaf area per branch was then used to scale up the number of branches at each transect location, which was then averaged to estimate an ecosystem-level LAI for S. pulchra.

\subsection{Chamber measurements}

For $\mathrm{CH} 11$, two chamber systems were used to measure isoprene fluxes: a larger static chamber and a smaller dynamic chamber. For the chamber measurements, isoprene concentrations were determined by collecting solid absorbent cartridges in the field and followed by analysis in the laboratory (see Supplement for further details). The static measurements were made with transparent acrylic chambers that were fitted to permanently white polypropylene chamber bases that were installed in each plot in June 2009. Over the course of 4 days, 15 separate measurements across 6 different pre-installed chamber bases were performed. The relative abundance of species present in the chambers is given in Table 1 and is representative of moist acidic tundra ecosystems. The chamber was approximately $35 \mathrm{~cm}$ in height (including the base) and $1.2 \mathrm{~m}$ on each side, enclosing a ground-surface area of $1.46 \mathrm{~m}^{2}$. The bases were installed for a project measuring whole-system $\mathrm{CO}_{2}$ isotopes. A static chamber technique was employed with 4 box fans in the chamber to promote mixing. Cartridge samples were collected over 15 to $20 \mathrm{~min}$ to calculate the change in isoprene concentration with time. Sampling began 2 to $5 \mathrm{~min}$ after the chamber was in place and each cartridge was filled for $5 \mathrm{~min}$. For each measurement 3 to 4 cartridges were collected and then the cartridges were analysed using the procedures outlined in the Supplement. Static chambers have the disadvantage of 
Table 1. Relative occurrence of species in the static chambers.

\begin{tabular}{lr}
\hline Species & Relative occurrence (\%) \\
\hline Mosses & 17.7 \\
Eriphorum vaginatum & 14.8 \\
Hylocomium splendens & 12.5 \\
Vaccinium uliginosum & 7.3 \\
Carex bigelowii & 6.8 \\
Cassiope tetragona & 6.6 \\
Lichens & 6.5 \\
Vaccinium vitis-idaea & 4.3 \\
Betula nana & 3.3 \\
Sphagnum spp. & 3.2 \\
Bryum spp. & 2.4 \\
Arctostaphylous alpina & 2.3 \\
Ledum palustre & 2.2 \\
Salix pulchra & 2.1 \\
Andromeda polyfolia & 1.5 \\
Dryas integrifolia & 1.4 \\
Polygonum vivparum & 1.1 \\
Others below 1\% & 4.3 \\
\hline
\end{tabular}

perturbing environmental conditions, and in particular lead to increasing air and leaf temperatures (Ortega and Helmig, 2008). To compensate for this, air temperature was continuously monitored with a thermocouple inside the chamber and light with a PAR sensor (model MQ, Apogee Instruments, Logan, Utah, USA). Also, immediately after removing the chamber, leaf/ground temperatures were measured with an infrared thermometer inside and outside the chamber base to assess the impact of heating.

In addition, leak rates were significant, since isoprene concentrations inside the chamber were much higher than outside concentrations (typically by a factor of 100). High chamber concentrations can lead to an underestimate of flux rates with the static enclosure technique (Nay et al., 1994). We used a simple model to predict the ecosystem exchange factor $\left(\mathrm{EF}_{\text {canopy }}\right)$ using Eq. (4) and a leak rate. The leak rate was estimated to be $7 \% \mathrm{~min}^{-1}$ assuming the amount of isoprene lost was proportional to concentration and based on measuring the decrease in isoprene concentration when the chamber was covered with a tarp (performed twice). The model predicted isoprene concentrations with a one-minute time step by using Eq. (4) to estimate emissions and then accounting for the loss of isoprene due to the leak rate. The basal emission rate was determined iteratively by minimizing the residual sum of squares calculated from the measured isoprene concentrations.

Dynamic chamber measurements were also employed with smaller chambers. These smaller dynamic chambers were located to only enclose Sphagnum ssp. Similar to the larger static chambers, these chambers had pre-existing bases placed in the ground and the placement of the chamber top did not physically touch any plant matter. The smaller dynamic chambers were circular, with a diameter of $19.2 \mathrm{~cm}$, a height of 5 to $10 \mathrm{~cm}$ and an enclosed surface area of $290 \mathrm{~cm}^{2}$. The flow rate through the chamber was $0.9 \mathrm{~L} \mathrm{~min}^{-1}$. Fluxes were calculated by measuring the isoprene concentration of air exiting the chamber and subtracting the concentration of isoprene measured in the air entering the chamber, which was not scrubbed for $\mathrm{O}_{3}$ or hydrocarbons. Because of low ambient $\mathrm{O}_{3}$ concentrations and the low reactivity of isoprene with $\mathrm{O}_{3}$, we assume chemical loss of isoprene was small. Two measurements were made of the isoprene concentration exiting the chamber and the results were averaged. Sample collection began at 6 and $30 \mathrm{~min}$ after enclosure, and each sample was collected for 20 min onto a cartridge and analysed using the procedures described in the Supplement. Temperature and light were measured with the same equipment described for the static chambers.

\subsection{Atmospheric chemistry model}

The impact of isoprene emissions on Arctic atmospheric chemistry was investigated with the RACM2 model (Regional Atmospheric Chemistry Mechanism, version 2, Stockwell and Goliff, 2004; Papiez et al., 2009). By running RACM with and without isoprene emissions and observing how the predicted concentrations of reactive species varied with time, we could assess how isoprene emissions influence atmospheric chemistry. This model includes a comprehensive isoprene oxidation scheme and lumps chemical species together for computational efficiency. The RACM2 mechanism was used in a box model mode, assuming a fixed convective boundary layer (CBL) height of $1000 \mathrm{~m}$. The model has zero spatial dimensions, so the CBL height is only used for the dilution of the isoprene emission source. Measurements at a similar latitude found a CBL height of $750 \mathrm{~m}$ (Liberto et al., 2012), and using $1000 \mathrm{~m}$ provides a lower-bound estimate on the impact of isoprene on chemical processes. The model output step was $30 \mathrm{~min}$ and ran from 07:00 to 01:00 the following day, local Alaska Daylight Time. Photolysis rates used for driving the model chemistry were generated using the appropriate time, date and latitude with the assumption of clear-sky conditions. Isoprene was added for each 30 min time step using emissions observed during day 180 of EC05. The model was also run with these emissions set to zero to analyse the impact of emissions on chemical processes. The initial concentrations of reactive gases were selected based on observations obtained during the ABLE 3 A study (Table 2), primarily near Barrow, Alaska.

\section{Results and discussion}

\subsection{Leaf-level emission rates}

\subsubsection{Temperature and light response}

Leaf-level rates of isoprene emission were explored as a function of leaf temperature and light (Fig. 2). We used 
Table 2. Concentrations and sources used to initialize the RACM model. PAN is peroxyacyl nitrates. Any chemical species not listed but that is tracked by the model (for example, methyl vinyl ketone and methacrolein) were initialized to zero.

\begin{tabular}{lrrr}
\hline Species & Concentration & Units & Source \\
\hline $\mathrm{O}_{3}$ & 32 & $\mathrm{ppb}$ & (Gregory et al., 1992) \\
$\mathrm{NO}$ & 8.5 & $\mathrm{ppt}$ & (Sandholm et al., 1992) \\
$\mathrm{NO}_{2}$ & 16.5 & $\mathrm{ppt}$ & (Sandholm et al., 1992) \\
$\mathrm{HNO}_{3}$ & 40 & $\mathrm{ppt}$ & (Talbot et al., 1992) \\
$\mathrm{PAN}_{\mathrm{CO}}$ & 25 & $\mathrm{ppt}$ & (Singh et al., 1992) \\
$\mathrm{CH}_{4}$ & 90 & $\mathrm{ppb}$ & (Harriss et al., 1992a) \\
Ethyne & 1.73 & $\mathrm{ppm}$ & (Harriss et al., 1992a) \\
Toluene & 40 & $\mathrm{ppt}$ & (Blake et al., 1992) \\
Benzene & 47 & $\mathrm{ppt}$ & (Rasmussen and Khalil, 1983) \\
& 167 & $\mathrm{ppt}$ & (Rasmussen and Khalil, 1983) \\
\hline
\end{tabular}

Eq. (1) to compare our measurements to predictions from the well-tested algorithms of Guenther et al. (1993). No adjustments were made to the coefficients of the published algorithm. The fit to temperature is good, with the algorithm explaining $96 \%$ of the observed variation (Fig. 2, left panel). The fit for light was less satisfactory and only $58 \%$ of the variation was explained. The response to light is more linear than predicted by the algorithm, which also has been observed in tropical ecosystems (Keller and Lerdau, 1999). Optimizing the parameters $\alpha$ and $C_{L 1}$ explains $81 \%$ of the variance, an improvement.

Our next goal was to determine the average basal emission rate $\left(\mathrm{EF}_{\text {leaf }}\right.$ in Eq. 1) for S. pulchra. We measured 21 independent leaves from a location approximately $500 \mathrm{~m}$ southwest of the field station. These leaves were located in the control plots of an experiment to measure the impact of nutrient addition and warming on the tundra ecosystem (Chapin et al., 1995). The average emission rate from these measurements at a leaf temperature of $25^{\circ} \mathrm{C}$ and $1000 \mu \mathrm{mol} \mathrm{m}{ }^{-2} \mathrm{~s}^{-1}$ PAR was $6.85(\mathrm{SD}=5.87) \mathrm{nmol} \mathrm{m}^{-2} \mathrm{~s}^{-1}$. Using measured dry leaf mass to express this on a gram dry weight (gdw) basis, the average rate is $15.1 \mu \mathrm{g} \mathrm{Cgdw}^{-1} \mathrm{~h}^{-1}$. Since the Guenther algorithm for temperature worked well with our data set, we can use Eq. (3) to estimate the rate at $30^{\circ} \mathrm{C}$ to be $27.4 \mu \mathrm{g} \mathrm{Cgdw}^{-1} \mathrm{~h}^{-1}$ to compare our results to measurements from temperate ecosystem plants. Our measured rate is very close to the average $\left(27.2 \mu \mathrm{g} \mathrm{Cgdw}^{-1} \mathrm{~h}^{-1}\right)$ which has been previously reported in the BVOC emission inventory for all Salix species (Wiedinmyer, 2004). Overall, the leaf-level isoprene emissions from $S$. pulchra located in the moist acidic tundra ecosystem were consistent with previous results from mid-latitude ecosystems, except that the response to light was more linear than predicted. The agreement in the basal emission rate and response to temperature has been noted previously in high-latitude ecosystems for a range of species (Karl et al., 2009 and references therein) and specifically for Salix at lower latitudes (Copeland et al., 2012).

\subsubsection{Global change factor experiment}

There were no significant differences observed in leaf-level isoprene emission rates from $S$. pulchra for any of the nutrient addition treatments versus the control: $p=0.98$ for $\mathrm{N}$, $p=0.98$ for $\mathrm{P}$ and $p=0.99$ for NP. This was contrary to our expectation, since, in particular, nitrogen fertilization has been shown to increase isoprene emission rates for temperate species (Harley et al., 1994). Our results are consistent with a recent report that also found no impact of fertilization on isoprene emissions from a similar Salix species (S. phylicifolia) treated to a similar fertilization experiment in Abisko, Sweden (Rinnan et al., 2011). On the other hand, the greenhouse warming experiment lead to an over 3-fold increase in isoprene emission rates (standard errors): from $4.49(0.79)$ to 13.92 (2.92) nmol m${ }^{-2} \mathrm{~s}^{-1}(p<0.01$ from Tukey's Honest Significant Difference, $n=4)$. This result is not explained by a difference in specific leaf weight, which increased only $3.4 \%$ in greenhouse; this difference is not significant (t-test, $p=0.73$ ). As summarized in Bret-Harte (2001), the main effect of the greenhouse is to increase air temperature, but two side effects are decreased PAR and decreased relative humidity. Decreasing PAR would suppress emissions (Harley et al., 1996), so this does not drive the observed increase in the basal emission rate. In isolation, changes in relative humidity do not impact isoprene emission rates - for example, relative humidity is not included in the Guenther algorithms.

The increasing basal emission rate with a higher growth temperature is consistent with many previous studies on the impact of growth temperature on the isoprene emission capacity of plants (for an early reference, see Monson and Fall, 1989). Unlike the fertilization component, our results differ from the similar experiment performed in Sweden (Rinnan et al., 2011). Rinnan et al. observed no significant difference for the warming treatment on S. phylicifolia. Three observations may explain this discrepancy. (1) In the Sweden experiment, warming is accomplished with open-top tents that employ passive warming. By chance, cloudy weather caused the temperatures in the warmed plot to be the same as the control plot at the time of measurement. Although our protocol of using detached leaves makes the instantaneous temperature the same $\left(25^{\circ} \mathrm{C}\right)$, short-term effects (5 to 10 days) could be influencing the basal emission rate (Petron et al., 2001; Grote and Niinemets, 2008; Monson et al., 2012) in our results. (2) The amount of warming in the two experiments differed. In our experiment, air temperatures were elevated in the range of 5 to $10^{\circ} \mathrm{C}$, while in the Sweden experiment the average was $4^{\circ} \mathrm{C}$ (see Sect. 2.1 in Rinnan et al., 2011). (3) The statistical power in the Sweden experiment is relatively low $(n=3)$, and true differences in the mean may have been masked by high variability (see Table 2 in Rinnan et al., 2011). Our replication is also low $(n=4)$, but the large difference in means and lower variability results in a significant difference ( $p<0.01$ as noted above). 


\subsection{Whole-ecosystem emissions}

\subsubsection{Eddy covariance measurements}

We measured whole-system isoprene fluxes at the Imnavait Creek field site during the summer of 2005 (EC05) and we observed fluxes exceeding $1.2 \mathrm{mg} \mathrm{m}^{-2} \mathrm{~h}^{-1}$ on day 180 (June 29) (Fig. 3). This maximum value is just over $50 \%$ higher than a previous report $\left(0.73 \mathrm{mg} \mathrm{C} \mathrm{m}^{-2} \mathrm{~h}^{-1}\right)$ for highlatitude Salix plantation $\left(58^{\circ}\right.$ N, Olofsson et al., 2005). To put this in perspective, a northern hardwood forest in Michigan had average midday fluxes of $3 \mathrm{mg} \mathrm{C} \mathrm{m}^{-2} \mathrm{~h}^{-1}$ over the entire growing season (Pressley et al., 2005), and several short data sets of emissions from tropical ecosystems give estimates of approximately $2.5 \mathrm{mg} \mathrm{C} \mathrm{m}^{-2} \mathrm{~h}^{-1}$ (Rinne et al., 2002; Karl et al., 2004). This tundra ecosystem has a much lower LAI than both the mid-latitude and tropical forested ecosystems. In addition, the average daily temperatures during the growing season are also much lower for tundra ecosystems. Lower LAI and lower average temperature are factors that decrease whole-system isoprene emissions (Guenther et al., 2006).

The record from EC05 is relatively short since this was an exploratory experiment and logistics constrained the amount of data collected. In addition, after day 180 the weather turned much cooler: air temperature did not exceed $10^{\circ} \mathrm{C}$ for the following week. This cool weather prevented further meaningful flux measurements. As seen on day 182, these low temperatures completely suppress isoprene emissions, even though light levels exceeded $1500 \mu \mathrm{mol} \mathrm{m}^{-2} \mathrm{~s}^{-1}$. This result is expected, since Eq. (3) decreases by a factor of 4 when the temperature decreases from 20 to $10^{\circ} \mathrm{C}$. Given the short span of our experiment, we did capture one of the warmest days of the growing season. Only for two consecutive days in August did air temperature exceed the level reached on day 180.

For EC10, one day (190) had temperatures that exceeded $20^{\circ} \mathrm{C}$ and were similar to day 180 in EC05 (Fig. 4). In this case, isoprene emission fluxes reached over $0.8 \mathrm{mg} \mathrm{C} \mathrm{m}^{-2} \mathrm{~h}^{-1}$. Because of the short nature of both data sets, we cannot assume this observed difference represents a true difference in the underlying capacity of the ecosystem to emit isoprene. From the experimental error perspective, estimation of sensible and latent heat fluxes by the eddy covariance can be off by $20 \%$ (Goulden et al., 1996). This should be considered a lower bound for the error in our isoprene fluxes, and could potentially explain half of the observed difference between EC05 and EC10.

But given the uncertainty in our measurements due to their limited length, the change in observed emission rates at similar conditions for light and temperature could be due to preceding air temperatures. The capacity to emit isoprene $\left(\mathrm{EF}_{\text {leaf }}\right.$ in Eq. 1) varies with the previous temperature experienced by leaves. For oaks, Petron et al. (2001) observed that isoprene emission at a leaf temperature of $30^{\circ} \mathrm{C}$ doubled when the growth temperature increased from 25 to $30^{\circ} \mathrm{C}$. In $\mathrm{EC} 05$, the
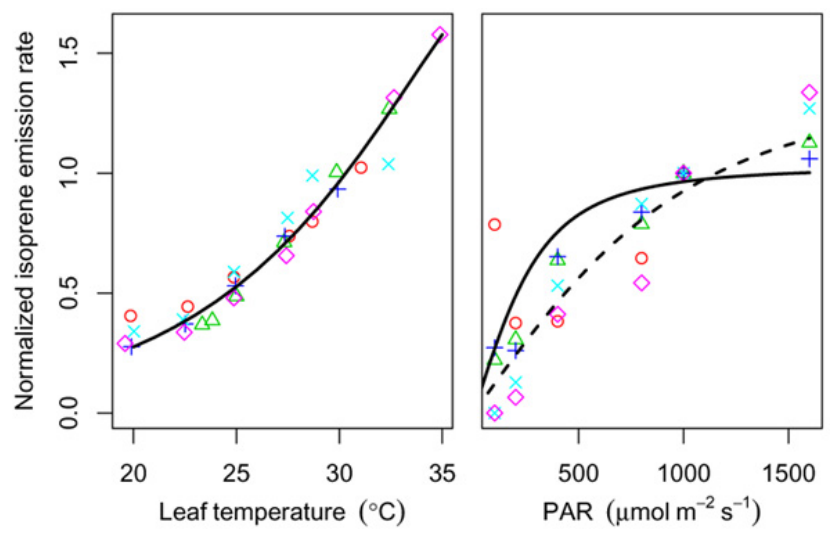

Fig. 2. Normalized isoprene emissions as a function of leaf temperature and light for S. pulchra leaves compared to the G93 algorithm (black curves). The dashed curve in the right-hand panel is the same algorithm with the $\alpha$ and $C_{L 1}$ parameters in Eq. (2) optimized to fit the data. The individual sets of measurements from the same leaf are denoted by the same colour and type of plotting character.
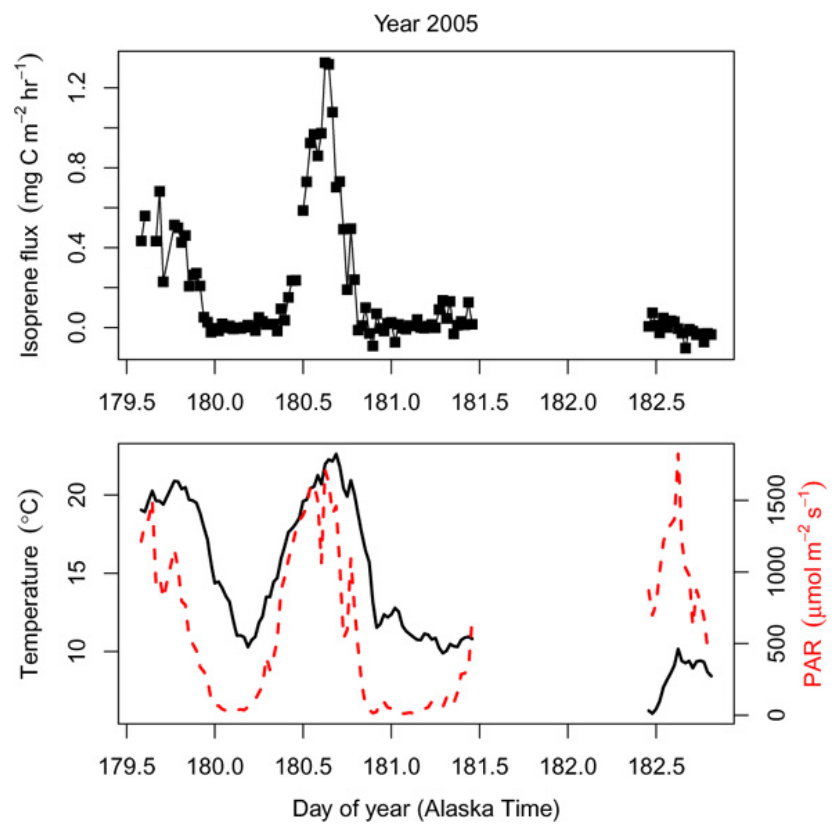

Fig. 3. Ecosystem-level fluxes of isoprene (top panel) and temperature (black, solid line) and photosynthetically active radiation (red, dashed line) for 2005 (bottom panel). The system was not run from day 181 to 192 since light and temperature were suppressed by ground fog.

maximum temperature increased linearly from 13 to $20^{\circ} \mathrm{C}$ in the 5 days preceding day 180 . In EC10, although the air temperature reached almost $20^{\circ} \mathrm{C}$ on the day previous to 190 , the temperature had not exceeded $10^{\circ} \mathrm{C}$ in the 3 days previous to that (186-188 days, Fig. 4).

MEGAN uses two time periods to model the impact of previous temperature: 1 day and 10 days. Using these metrics, 
EC05 and EC10 are similar. For the previous 1 day, the average temperature was $16.8^{\circ} \mathrm{C}$ in 2005 and $19.0^{\circ} \mathrm{C}$ in 2010 , while for the previous 10 days, the averages were $10.5^{\circ} \mathrm{C}$ (2005) and $10.4^{\circ} \mathrm{C}(2010)$. The algorithm in MEGAN would predict a $12 \%$ higher emission capacity in 2010 compared to 2005 because of the $2.2{ }^{\circ} \mathrm{C}$ increase in averaged air temperature over the preceding 1 day, while the small $0.1^{\circ} \mathrm{C}$ change over the preceding 10 days results in a change of less than $1 \%$. The predicted $12 \%$ increase is opposite of the observed decrease in emissions from 2005 to 2010 under similar temperature and light conditions. But as mentioned above, the air temperatures in 2010 were much cooler 2 days before the warm day. Using 5 days as the averaging period, in 2005 the average temperature was $14.9^{\circ} \mathrm{C}$ while it was $9.7^{\circ} \mathrm{C}$ in 2010 . Again, we cannot confirm the role of previous temperature given these two relatively short measurement periods, but variations in tundra ecosystem's capacity to emit isoprene $(\varepsilon$ in Eq. 5) warrant further study.

The shape of the diurnal cycle of isoprene emissions is similar to the shape observed for mid-latitude ecosystems (compare our Figs. 3-5 in Baldocchi et al., 1995). Night-time emissions are near zero in both cases. Since isoprene emissions require light (cf. Eq. 2), this is the expected result for the mid-latitude ecosystem. Because Toolik is located above the Arctic Circle near $69^{\circ} \mathrm{N}$, the sun never set during EC05 or EC10 so this is a less obvious result. But the diurnal cycle in temperature and light were sufficient to suppress nighttime isoprene emissions (Figs. 3 and 4). The peak in isoprene emissions occurs around 15:00 LT (Fig. 3) in 2005, which is $1 \mathrm{~h}$ after solar noon (14:00 LT) and corresponds to the peak in air temperature. Again, this result is consistent with midlatitude ecosystems (e.g., Pressley et al., 2005).

\subsubsection{Chamber measurements}

Static chamber measurements of whole-system isoprene fluxes were performed 6-9 July (187-190 days of year) during 2011. Over these 4 days, 15 samples were collected from 6 different installed bases. Of this set, 4 samples were rejected because our technique of using observed temperature and PAR and a fixed leak rate explained less than $55 \%$ of the variation in isoprene concentration (average $r^{2}=0.26$ ). In 2 of these four rejected cases, clouds passed overhead during the measurement and changed PAR values measured inside the enclosure by a factor of 3 . Excluding these 4 cases only causes a $5 \%$ increase in the result. For the 11 samples retained, our model explained on average $95 \%$ of the observed variation in isoprene concentrations. The mean of these measurements was $0.45(\mathrm{SD}=0.19) \mathrm{mg} \mathrm{C} \mathrm{m}^{-2} \mathrm{~h}^{-1}$. Because our static chamber model was based on Eq. (4), this result is effectively $\mathrm{EF}_{\text {canopy }}$ and can be compared to the $\mathrm{EF}_{\text {canopy }}$ values calculated for the EC05 and EC11 measurements in Fig. 5. The slope of the line for each year gives $\mathrm{EF}_{\text {canopy }}: 1.93$ (EC05) and 0.93 (EC10) $\mathrm{mg} \mathrm{C} \mathrm{m}^{-2} \mathrm{~h}^{-1}$. We considered three factors that could explain the differences in

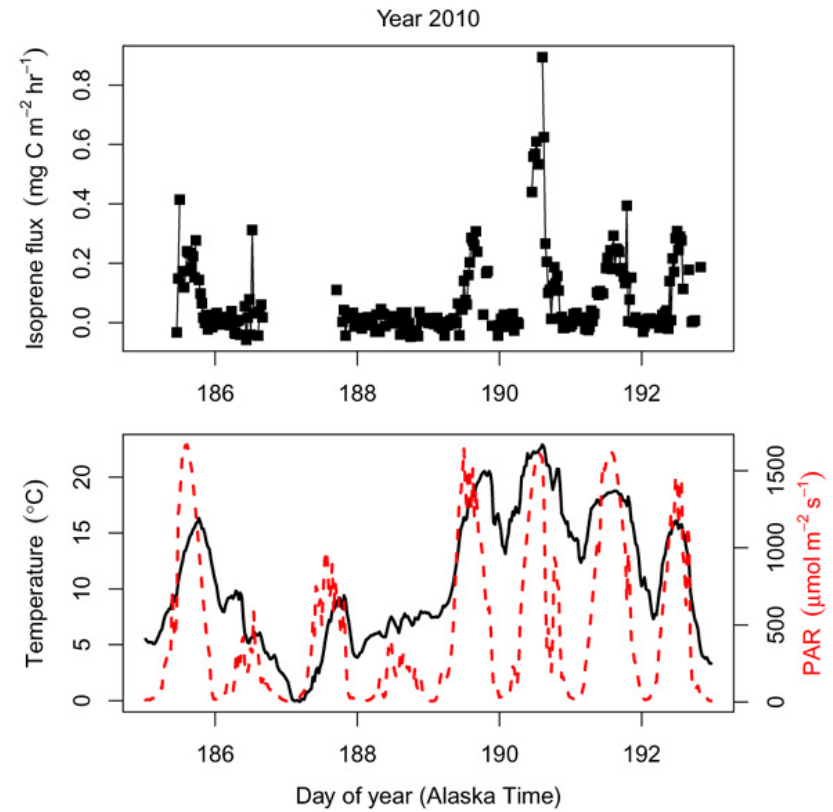

Fig. 4. Ecosystem-level fluxes of isoprene (top panel) and temperature (black, solid line) and photosynthetically active radiation (red, dashed line) for 2010 (bottom panel).

emission rates observed between the $\mathrm{CH} 11$ and EC05/EC10 measurements: chamber effects on measured air temperature, previous temperature and ecosystem composition.

Both the eddy covariance and chamber $\mathrm{EF}_{\text {canopy }}$ estimates are based on air temperature, which is an imperfect proxy for the leaf temperature driving isoprene emissions because solar heating elevates leaf temperature above air temperature (see Sect. 2.2). But this elevation of leaf versus air temperature could differ for the chamber measurements versus the eddy covariance measurements for two reasons. First, the air temperature measurement is much closer to the ground ( 20 to $30 \mathrm{~cm}$ vs. $2 \mathrm{~m}$ ). Second, solar radiation is reduced by chamber top. If the net impact is a reduction of the difference between air and leaf temperature, this creates a bias towards lower estimates of $\mathrm{EF}_{\text {canopy }}$ by the chamber method compared to the eddy covariance method. This could explain some of the observed discrepancy in addition to the reasons below.

The importance of variability due to previous temperature regime was discussed above for the eddy covariance results. Air temperature data were available from a nearby (less than $1 \mathrm{~km}$ ) weather station operated by the Environmental Data Team of the Toolik Field Station (http://toolik. alaska.edu/edc/abiotic_monitoring/data_query.php). Over the 4-day sampling period, the $24-\mathrm{h}$ average previous temperature ranged from 9.6 to $14.0^{\circ} \mathrm{C}$, considerably lower than either EC05 $\left(16.8^{\circ} \mathrm{C}\right)$ or EC10 $\left(19.0^{\circ} \mathrm{C}\right)$. Similarly, the 10 day average temperature ranged from 8.7 to $9.4^{\circ} \mathrm{C}$, again lower than the 10.5 and $10.4{ }^{\circ} \mathrm{C}$ observed for EC05 and EC10, respectively. The lower values of $\mathrm{EF}_{\text {canopy }}$ observed 


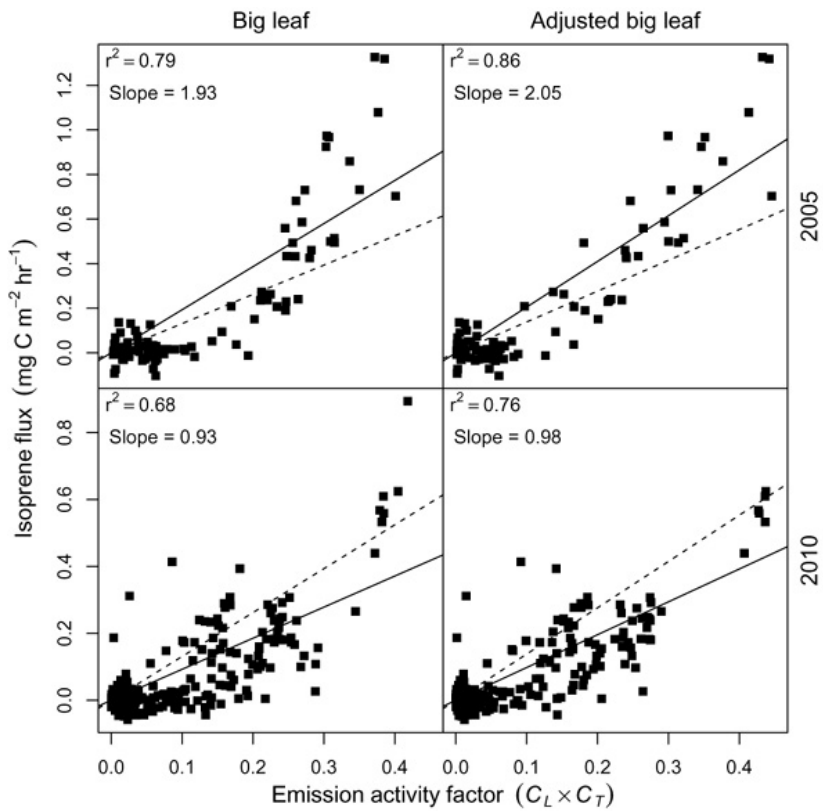

Fig. 5. Left-hand panels: a model of whole-ecosystem isoprene fluxes using the G93 algorithms and treating the tundra as a single "big leaf" for each year (Eq. 4). Model predictions of the impact of temperature and light $\left(C_{L} \times C_{T}\right)$ are on the x-axis, the measurements of whole-system isoprene emissions (Emission canopy $_{\text {) are on }}$ the $y$-axis and the canopy emission factor $\left(\mathrm{EF}_{\text {canopy }}\right)$ is the slope of the fitted line. Right-hand panels: the same model (Eq. 4), except that the $\alpha$ and $C_{L 1}$ parameters in the G93 algorithm for light (Eq. 2) have been optimized. The solid line is the linear fit with a zero intercept between the model and the observations for each individual year. The dashed line is the same fit for both years (EC05 and EC10) combined. The statistics for the combined fit with the original bigleaf model (two left-hand panels) are $r^{2}=0.66$ and slope $=1.31$ and with the adjusted big-leaf model (two right-hand panels) are $r^{2}=0.73$ and slope 1.38 .

for $\mathrm{CH} 11$ are consistent with the influence of previous temperatures.

Although the CH11 and EC05/EC10 measurements were both taken from moist acidic tundra ecosystems, there were differences between the sampling locations (Fig. 1). In particular, less $S$. pulchra was present in the ecosystems enclosed by the chambers (CH11). The average percent cover for $S$. pulchra was $2.1 \%$ within the chamber bases (Table 1). For the moist acidic tundra ecosystem near the Imnavait Creek flux tower (EC experiments), we estimated an LAI of 0.054 for S. pulchra from our transect data, compared to a total LAI of 0.66 from the literature (Williams et al., 2006). This gives a percent coverage of $8.2 \%$, approximately 4 times that observed within the chamber bases for $\mathrm{CH} 11$. This moist acidic tundra ecosystem in the footprint of the tower consists of evergreen shrubs, the deciduous shrubs, the sedge Eriophorum vaginatum and mosses, and this ecosystem type dominates the ground cover $(95 \%$; for complete details see Sect. 2.2 in Kade et al., 2012). The impact of this increase in S. Pulchra coverage on the predicted canopy emission factor is explored below under the whole-system modelling section.

Isoprene fluxes observed from the smaller dynamic chambers enclosing only Sphagnum spp. were much lower than observed from the larger static chambers. The data were collected simultaneously (8-9 July, 189-190 days of year) and at the same location. No measurements from the dynamic chambers exceeded $0.038 \mathrm{mg} \mathrm{C} \mathrm{m}^{-2} \mathrm{~h}^{-1}$, which was less than $10 \%$ of the values observed from the static chambers. These smaller dynamic chambers were selectively placed over Sphagnum spp. (moss). Given the uncertainties inherent in using different measurement techniques, we conclude that the mosses do not contribute significantly $(<10 \%)$ to the entire ecosystem flux of isoprene, which is in agreement with a study that found vascular plants contributed over $90 \%$ of the isoprene flux from a boreal peatland (Tiiva et al., 2009). We do note that Sphagnum ssp. have complex controls related to photosynthesis and water availability which could affect their contribution to ecosystem isoprene flux under different environmental conditions (Ekberg et al., 2011).

\subsection{Whole-system modelling}

We tested a very simple model of isoprene emission considering the tundra ecosystem as a "big leaf" (Eq. 4). We were motivated to investigate the use of a big-leaf model because of the relatively short height of plants in the tussock tundra ecosystem and relatively low LAI (LAI $=0.66$, Williams et al., 2006). While the model has some predictive capability (solid lines in the 2 left panels of Fig. 5), the model overpredicts at low emission levels and under-predicts at high emission levels, especially in 2005. Results from leaf-level measurements (Fig. 2) demonstrate that these emission algorithms (with parameters derived from temperate species research) perform well for temperature but less satisfactorily for light. Following our results at the leaf-level, we computed a canopy emission factor based on the optimized parameters $\alpha$ and $C_{L 1}$ determined from the light-response curve data (Fig. 2). The fraction of variance explained by this modification to the model increased for each year ( 0.79 to 0.86 for 2005 and 0.68 to 0.76 for 2010).

Although this fit is very good, we were concerned if the model was actually capturing the underlying processes well or if there was covariance between explanatory variables that gave a satisfactory result only valid for our short data set. Our major concern was the covariance of temperature and light in the data sets and the influence of leaf temperature elevation versus air temperature. Measurements with an infrared thermometer found leaf/ground temperatures reaching up to $10^{\circ} \mathrm{C}$ above air temperatures in 2005 (data not shown). The motivation to adjust the light relationship by optimizing $\alpha$ and $C_{L 1}$ was based on the leaf-level observations. At the whole-system level, straightening the light-response curve might give a good fit to the data, but the underlying 
response at higher light levels could be a combination of two processes. First, isoprene emissions at the leaf-level plateau with increasing light as predicted by Eq. (2). Second, the increasing light levels increase leaf temperature at a constant air temperature. The overall effect would appear to be a more linear increase at high light levels. This would be a problem since our big-leaf model uses air temperature, not leaf temperature. To test this concern, we moved to a more sophisticated isoprene emission model which estimates leaf temperatures: MEGAN.

The switch to MEGAN, driven by default values from the global database (Guenther et al., 2006), significantly improved the fit versus the big-leaf model (compare left-hand panels of Fig. 5 to left-hand panels of Fig. 6). For the data set in 2005, the $r^{2}$ values increased from 0.79 to 0.86 and in 2010 they increased from 0.68 to 0.74 . Interestingly, the results from MEGAN are almost the same as the adjusted bigleaf model with optimized coefficients (compare right-hand panels of Fig. 5 to left-hand panels of Fig. 6).

In addition to improving the fit, the MEGAN model also provides an absolute value for the flux to compare to our measured values (Eq. 5). The only adjustment to MEGAN was to use the LAI value with no bare cover. Based on remote sensing data, the grid cell that includes the Toolik area is considered to be $42.5 \%$ bare in the MEGAN database. This is appropriate for the entire cell, but not for the fully vegetated area within the flux tower footprint. For 2005, the fit to default values from MEGAN is surprisingly good: on average, the modelled fluxes are only $18 \%$ higher than the observed fluxes (Fig. 6, top-left panel). As discussed in Sect. 3.2.1, measured whole-system fluxes were higher in 2005 compared with 2010, although environmental conditions were similar. This is also reflected in the comparison of the MEGAN model to the measured fluxes for 2010; the measurements are on average only $40 \%$ of the MEGAN values (Fig. 6, bottom-left panel). Interestingly, some of the highest fluxes measured are much closer to the one-to-one line than lower fluxes.

Again, we explored if this good fit to the global estimate in MEGAN reflected our full understanding of the properties associated with this moist acidic tundra ecosystem. First, the LAI used by MEGAN based on remote sensing data is 1.6. This is much higher than the value typically measured for moist acidic tundra (0.66, Williams et al., 2006) and estimated from a whole-system $\mathrm{CO}_{2}$ exchange model and measured $\mathrm{CO}_{2}$ fluxes from the same tower (0.3-0.6, see Fig. 6 in Rastetter et al., 2010). For the second version of the MEGAN model ("localized"; right-hand panels in Fig. 6), we set $\mathrm{LAI}=0.66$.

The next modification was to use a canopy emission factor ( $\varepsilon$ in Eq. 5) based on our results from leaf-level and chamber measurements. As a baseline, we used $0.45 \mathrm{mg} \mathrm{C} \mathrm{m}^{-2} \mathrm{~h}^{-1}$ from our chamber measurements. As noted above, there was little $S$. pulchra within the bases used for the chamber measurements: the ground cover of S. pulchra was $2.1 \%$. We

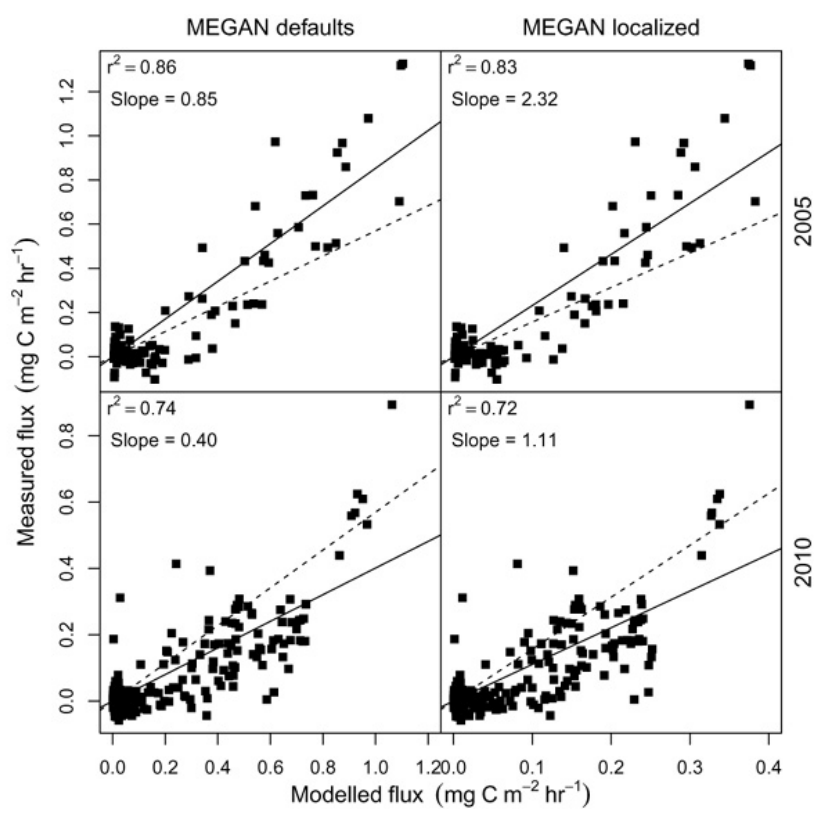

Fig. 6. Comparison of whole-ecosystem isoprene fluxes measured to the MEGAN emission model. Model predictions of the Emission $_{\text {canopy }}$ are on the $\mathrm{x}$-axis and the measurements of wholesystem isoprene emissions are on the y-axis. Left-hand panels: output using the default parameter values from MEGAN's global database. Right-hand panels: output using parameter values estimated for the moist acidic tundra ecosystem. The solid line is the linear fit with a zero intercept between the model and the observations for each individual year. The dashed line is the same fit for both years (EC05 and EC10) combined. The statistics for the combined fit with MEGAN defaults (two left-hand panels) are $r^{2}=0.72$ and slope $=0.70$ and with MEGAN localized (two right-hand panels) are $r^{2}=0.70$ and slope 1.57 .

ascribe the emissions observed from the static chambers to sedge species. We did not conduct an extensive survey of leaf-level emissions from sedge species, but other investigators have found appreciable emissions (Ekberg et al., 2009). Averaging across species (Eriophorum angustifolium and Carex rostrata), year (2005 and 2006) and season (June through September) for the data reported Ekbert et al. (2009; Table 1,) and then using Eq. (3) to adjust to $30^{\circ} \mathrm{C}$, the average basal emission rate is $4.5 \mathrm{nmol} \mathrm{m}^{-2} \mathrm{~s}^{-1}$. This is $36 \%$ of the value we report for $S$. pulchra. To account for the increased abundance of S. pulchra at the EC05/10 site, we used the results of our transect survey of $S$. pulchra LAI (0.054). We combined this with our leaf-level emission rate $\left(12.4 \mathrm{nmol} \mathrm{m}^{-2} \mathrm{~s}^{-1}\right.$ for a leaf temperature of $30^{\circ} \mathrm{C}$ ) from $S$. pulchra to derive a new whole-system emission factor. Using the convention of MEGAN, $\varepsilon$ is standardized to an LAI of 5 and is $2.47 \mathrm{mg} \mathrm{C} \mathrm{m}^{-2} \mathrm{~h}^{-1}$ for the combined contribution from sedges and $S$. pulchra. The final modification was to switch the canopy type used by MEGAN, which affects a range of parameters, for example, canopy height, leaf width and reflection and scattering coefficients. The global default 
in MEGAN for our grid cell is shrub, while grass would be more appropriate for the tundra ecosystem. For example, canopy height is $2 \mathrm{~m}$ for shrubs but $0.5 \mathrm{~m}$ for grass; the later value is more accurate for the tundra ecosystem.

The results of the MEGAN using localized input values are shown in the right-hand panels of Fig. 6. The amount of variance explained by MEGAN decreases slightly for each year (0.86 to 0.83 for 2005 and 0.74 to 0.72 for 2010) with these changes applied. Note that the change to the canopy emission factor will not affect the fit (variance explained) of the model, so the slight decrease is due to the change in LAI and the change in canopy type from shrub to grass. We are unable to explain why the improvements in the input values to MEGAN did not correspond to an increase in MEGAN's predictive ability, but we note again that the data sets are short and the overall fits are good. The absolute fit is very good for EC10: the model under predicts measured fluxes by less than $10 \%$. But conversely, the model under prediction is much worse for EC05; the measured fluxes are a factor of 2.32 higher than predicted by MEGAN. This difference is consistent with our previous discussion of inter-annual effects.

\subsection{Atmospheric chemistry modelling}

Modelling results demonstrate the impact of the measured isoprene emissions on atmospheric chemistry (Fig. 7). Modelled isoprene concentrations reach almost $1.5 \mathrm{ppb}$, which is within the range of ambient concentrations observed during our chamber measurements (CH11): 0.64 to $1.61 \mathrm{ppb}$. In addition, 9 samples of ambient air were collected during the EC10 campaign, with an average value of $1.50 \mathrm{ppb}$. These measured isoprene concentrations were collected at ground level, so we also compare our modelled results to concentrations observed in the CBL during mission 21 of the ABLE $3 \mathrm{~A}$ campaign. In a vertical flight profile near Bethel, Alaska, over tundra and boreal forest ecosystems, isoprene concentrations ranged between 0.50 and 0.53 ppb below an altitude of $1000 \mathrm{~m}$ (see Fig. 17a in Blake et al., 1992). While these observed concentrations are lower than modelled, the strength of isoprene emissions in the flight source region is unknown. The sharp decrease in isoprene concentrations with height above $1000 \mathrm{~m}$ altitude supports our selection of that value for the CBL height. Observed ozone concentrations (30 to $31 \mathrm{ppb}$ ) during the same flight at the same altitudes are consistent with our initialization value (32 ppb).

With the inclusion of the isoprene source, the model predicts a greater than $50 \%$ reduction in the maximum hydroxyl radical (HO) concentration and even greater reductions past solar noon (14:00 LT). The loss rate of ozone increases with the addition of the isoprene source because of the direct reaction of ozone with the double carbon-carbon bonds in isoprene. This is in contrast to the situation over most of the contiguous United States, where isoprene emissions contribute to ozone formation (Chameides et al., 1988). The reason is

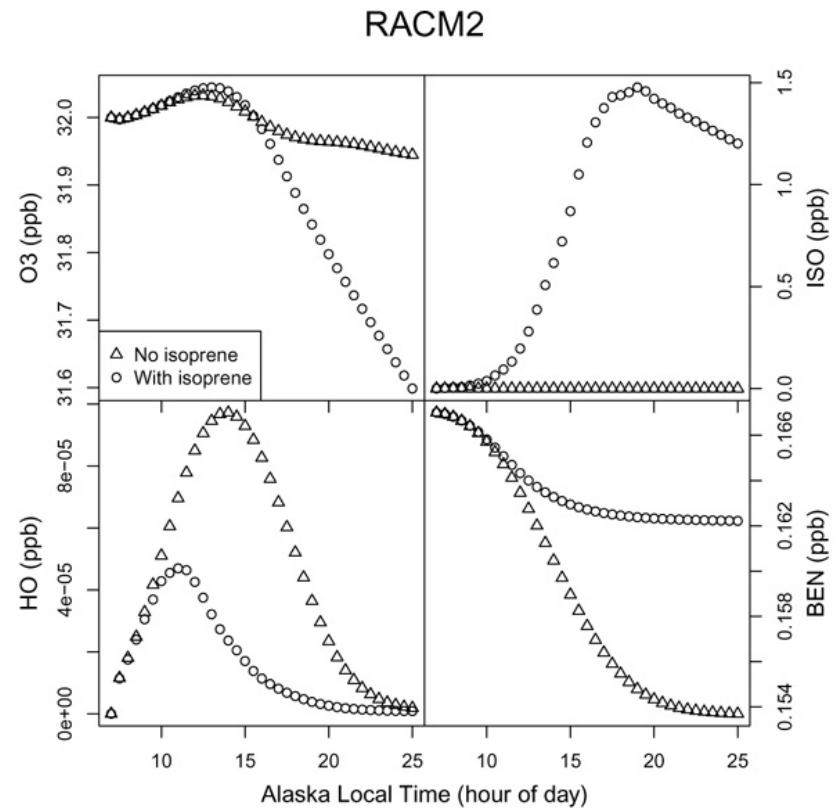

Fig. 7. Results from running a photochemical box model (RACM2) with (circles) and without (triangles) isoprene emissions. The model was driven with the isoprene emissions observed on day of year 180 during EC05. The model time domain reached day 01:00 LT on day of year 181, which is displayed as hour 25. Species codes: O3 is ozone $\left(\mathrm{O}_{3}\right)$, HO is the hydroxyl radical, ISO is isoprene and BEN is benzene $\left(\mathrm{C}_{6} \mathrm{H}_{6}\right)$. Note that solar noon occurs around 14:00 LT.

the relatively low $\mathrm{NO}_{\mathrm{x}}\left(\mathrm{NO}_{\mathrm{x}}=\mathrm{NO}+\mathrm{NO}_{2}\right)$ concentrations used in the model (see Table 2 for initialization values for all chemical species). Overall, these results demonstrate that the observed isoprene fluxes have a significant impact on atmospheric chemistry.

\section{Conclusions}

\subsection{Global isoprene models}

In order to test our hypotheses, we first needed to understand if current models of isoprene emission are adequate for tundra ecosystems and plant species. Our results lend support to the hypothesis of Arneth et al. (2008). Arneth et al. (2008) start with the observation that different groups modelling global isoprene emissions often converge on the same estimate (Table 1, Arneth et al., 2008). But they find this convergence "is in stark contrast with our lack of process understanding and the small number of observations for model parameterisation and evaluation" (abstract, Arneth et al., 2008). While our measured whole-system fluxes are in reasonable agreement with predictions from global models, this agreement was based on offsetting errors in two important parameters. First, the actual LAI of the ecosystem was lower than predicted by MEGAN (0.66 compared to 1.6). Second, the actual canopy emission factor was higher than predicted 
(3.74 compared to $2.47 \mathrm{mg} \mathrm{C} \mathrm{m}^{-2} \mathrm{~h}^{-1}$ ). While these errors offset each other to produce an overall modelled estimate that was close to our observations, this is only a fortuitous result. More generally, errors such as these demonstrate that much more experimental data are necessary to improve the parameters used by these models. Moving past improved parameterization and more to the point of Arneth et al. (2008), there are indications that the underlying algorithms used in MEGAN are not optimal for the tundra ecosystem. Adjusting two parameters in the algorithm improved the fit of the simple big-leaf model. Much longer data sets of whole-system emissions from a variety of ecosystem types need to be collected to fully understand the relevance of this observation.

\subsection{Arctic atmospheric chemistry}

The reduction in $\mathrm{OH}$ concentrations simulated by RACM has a significant impact on the chemical loss rate of a reactive hydrocarbon found in the Arctic due to long-range transport: benzene $\left(\mathrm{C}_{6} \mathrm{H}_{6}\right)$. The maximum chemical loss rate due to the reaction of benzene with $\mathrm{OH}$ decreases with the addition of isoprene by just over a factor of two (2.02, Fig. 7), which is equivalent to a doubling of chemical lifetime of benzene. Benzene is a reasonable surrogate for other hydrocarbons in the Arctic atmosphere. In particular, the chemical loss rates of persistent organic pollutants (POPs) are important for understanding their transport and fate in the Artic. Currently, investigators have hypothesized that Arctic warming is leading to remobilization of these POPs (Ma et al., 2011). We speculate that if remobilization continues to occur, redeposition of these POPs will increase in the Arctic because of the decrease in chemical oxidation. To fully predict future transport of these remobilized POPs, changes in chemical loss rates due to potential changes in isoprene emission rates should be considered.

\subsection{Global climate change and future emissions from Arctic ecosystems}

Based on our results, we predict that isoprene emissions from Arctic ecosystems will increase due to future climate change. Predicting future isoprene emissions from any ecosystem is a two-step process. First, the factors that control isoprene emissions must be identified and their relationship to emissions understood. Second, predictions of how the identified factors will change in the future are necessary. Temperature is the one factor that is relatively straightforward. A simple extrapolation using the Guenther algorithm (Eq. 3) and the predicted rise in global temperature over the next century $\left(2\right.$ to $\left.3{ }^{\circ} \mathrm{C}\right)$ gives an increase of 30 to $45 \%$ in predicted global isoprene emissions (Peñuelas and Llusià, 2003). For the Arctic, the temperature increase is expected to be greater than the global increase (IPCC, 2007), and BVOC emissions would be further amplified because of the exponential relationship between emissions and temperature (Eq. 3). This prediction is supported by our observation that the simulated warming experiment increased isoprene emission rates by a factor of 3. But this only considers the direct effect of temperature. The response of isoprene emission to other global change factors (nutrient addition, UV radiation, ozone, and drought stress) is more complicated, with isoprene emissions responding differently in different experiments (Peñuelas and Staudt, 2010). Further, the suppression of isoprene emissions by elevated $\mathrm{CO}_{2}$ concentrations can offset the increase predicted from increasing air temperatures (Arneth et al., 2007; Monson et al., 2007). In our data set, one global change factor, fertilization by nitrogen and phosphorous, had no impact on leaf-level isoprene emissions in our experiment.

Further, changes in ecosystem species composition due to changing climate could cause major shifts in the canopy emission factor $(\varepsilon)$. Increasing temperatures have caused an increase in woody shrubs in areas that are currently tundra ecosystems (Elmendorf et al., 2012). The shift towards Betula was observed in a warming experiment near the Toolik Field Station (Hobbie and Chapin, 1998), where the aboveground biomass of Betula nana increased almost two fold. We note that Salix was relatively rare at this experimental location. But another recent study found specifically that Salix growth would be favoured in the north-western Eurasian tundra due to teleconnections between atmospheric circulation and air-surface exchanges (Macias-Fauria et al., 2012).

If ecosystem changes lead to increases in the abundance of Salix or other isoprene-emitting genera, then there will be increases in $\varepsilon$. But if non-isoprene-emitting genera like $\mathrm{Be}$ tula (birch) increase, then $\varepsilon$ could decrease for isoprene. The impact on monoterpene and sesquiterpene emission capacities would be the opposite, since Betula is a significant emitter of these chemical compounds (Haapanala et al., 2009). This shift in the emissions profile would have impacts on atmospheric chemistry because of the relatively higher reactivity of these compounds compared to isoprene (see Table 2 in Fuentes et al., 2000). Similarly, monoterpenes and sesquiterpenes have higher aerosol yields which could lead to increases in secondary organic aerosol formation and associated impacts on climate (O'Dowd et al., 2002). In addition to changing $\varepsilon$ for isoprene, monoterpenes and sesquiterpenes, climate change could lead to increases in leaf biomass which could offset any reductions in $\varepsilon$. Our overall conclusion is that predicting future isoprene emissions from tundra ecosystems will rely both on a better understanding of the processes that control emissions from these high-latitude ecosystems and detailed predictions of future ecosystem future and composition. Given the uncertainty, we do predict that temperature will be the dominant factor, and that isoprene emissions from tundra ecosystems could become comparable to midlatitude ecosystems. 


\section{Supplementary material related to this article is

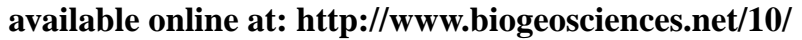 871/2013/bg-10-871-2013-supplement.pdf.}

Acknowledgements. The authors (MJP and BMB) gratefully acknowledge support from the National Science Foundation for a Collaborative Research award entitled Biogenic Volatile Organic Compound Emissions from the Tundra and Arctic Atmospheric Chemistry (1025948). This work was also supported by project no. 0221835 (Biocomplexity) and 0732664 (IPY) from the National Science Foundation to KLG and Arctic Natural Sciences Program, award 806776 to GS. We also thank Gus Shaver and John Hobbie from the Marine Biological Laboratory for advice, logistical support and access to the global change plots. Finally, we very much appreciate the logistical support we received from Chad Diesinger and the staff at the Toolik Field Station and Institute for Arctic Biology at the University of Alaska-Fairbanks.

Edited by: A. Arneth

\section{References}

Andreae, M. O. and Crutzen, P. J.: Atmospheric aerosols: Biogeochemical sources and role in atmospheric chemistry, Science, 276, 1052-1058, 1997.

Arneth, A., Miller, P. A., Scholze, M., Hickler, T., Schurgers, G., Smith, B., and Prentice, I. C.: $\mathrm{CO}_{2}$ inhibition of global terrestrial isoprene emissions: Potential implications for atmospheric chemistry, Geophys. Res. Lett., 34, L18813, doi:10.1029/2007g1030615, 2007.

Arneth, A., Monson, R. K., Schurgers, G., Niinemets, Ü., and Palmer, P. I.: Why are estimates of global terrestrial isoprene emissions so similar (and why is this not so for monoterpenes)?, Atmos. Chem. Phys., 8, 4605-4620, doi:10.5194/acp-8-46052008, 2008.

Arneth, A., Schurgers, G., Lathiere, J., Duhl, T., Beerling, D. J., Hewitt, C. N., Martin, M., and Guenther, A.: Global terrestrial isoprene emission models: sensitivity to variability in climate and vegetation, Atmos. Chem. Phys., 11, 8037-8052, doi:10.5194/acp-11-8037-2011, 2011.

Aubinet, M., Grelle, A., Ibrom, A., Rannik, U., Moncrieff, J., Foken, T., Kowalski, A. S., Martin, P. H., Berbigier, P., Bernhofer, C., Clement, R., Elbers, J., Granier, A., Grunwald, T., Morgenstern, K., Pilegaard, K., Rebmann, C., Snijders, W., Valentini, R., and Vesala, T.: Estimates of the annual net carbon and water exchange of forests: The EUROFLUX methodology, Adv. Ecol. Res., 30, 113-175, 2000.

Bakwin, P. S., Wofsy, S. C., Fan, S. M., and Fitzjarrald, D. R.: Measurements of Nox and Noy Concentrations and Fluxes over Arctic Tundra, J. Geophys. Res.-Atmos., 97, 16545-16557, 1992.

Baldocchi, D., Guenther, A., Harley, P., Klinger, L., Zimmerman, P., Lamb, B., and Westberg, H.: The Fluxes and Air Chemistry of Isoprene above a Deciduous Hardwood Forest, Philos. T. Roy. Soc. A, 351, 279-296, 1995.

Baldocchi, D. D., Fuentes, J. D., Bowling, D. R., Turnipseed, A. A., and Monson, R. K.: Scaling isoprene fluxes from leaves to canopies: Test cases over a boreal aspen and a mixed species temperate forest, J. Appl. Meteorol., 38, 885-898, 1999.

Baldocchi, D., Falge, E., Gu, L. H., Olson, R., Hollinger, D., Running, S., Anthoni, P., Bernhofer, C., Davis, K., Evans, R., Fuentes, J., Goldstein, A., Katul, G., Law, B., Lee, X. H., Malhi, Y., Meyers, T., Munger, W., Oechel, W., U, K. T. P., Pilegaard, K., Schmid, H. P., Valentini, R., Verma, S., Vesala, T., Wilson, K., and Wofsy, S.: FLUXNET: A new tool to study the temporal and spatial variability of ecosystem-scale carbon dioxide, water vapor, and energy flux densities, B. Am. Meteorol. Soc., 82, 2415-2434, 2001.

Baldocchi, D. D.: Assessing the eddy covariance technique for evaluating carbon dioxide exchange rates of ecosystems: past, present and future, Glob. Change Biol., 9, 479-492, 2003.

Barrie, L. A., Bottenheim, J. W., Schnell, R. C., Crutzen, P. J., and Rasmussen, R. A.: Ozone Destruction and PhotochemicalReactions at Polar Sunrise in the Lower Arctic Atmosphere, Nature, 334, 138-141, 1988.

Bartlett, K. B., Crill, P. M., Sass, R. L., Harriss, R. C., and Dise, N. B.: Methane Emissions from Tundra Environments in the YukonKuskokwim Delta, Alaska, J. Geophys. Res.-Atmos., 97, 1664516660, 1992.

Blake, D. R., Hurst, D. F., Smith, T. W., Whipple, W. J., Chen, T. Y., Blake, N. J., and Rowland, F. S.: Summertime Measurements of Selected Nonmethane Hydrocarbons in the Arctic and Sub-Arctic during the 1988 Arctic Boundary-Layer Expedition (Able-3a), J. Geophys. Res.-Atmos., 97, 16559-16588, 1992.

Boelman, N. T., Gough, L., McLaren, J. R., and Greaves, H.: Does NDVI reflect variation in the structural attributes associated with increasing shrub dominance in arctic tundra?, Environ. Res. Lett., 6, 035501, doi:10.1088/1748-9326/6/3/035501, 2011.

Bret-Harte, M. S., Shaver, G. R., Zoerner, J. P., Johnstone, J. F., Wagner, J. L., Chavez, A. S., Gunkelman, R. F., Lippert, S. C., and Laundre, J. A.: Developmental plasticity allows Betula nana to dominate tundra subjected to an altered environment, Ecology, 82, 18-32, 2001.

Chameides, W. L., Lindsay, R. W., Richardson, J., and Kiang, C. S.: The Role of Biogenic Hydrocarbons in Urban Photochemical Smog - Atlanta as a Case-Study, Science, 241, 1473-1475, 1988.

Chapin, F. S., Shaver, G. R., Giblin, A. E., Nadelhoffer, K. J., and Laundre, J. A.: Responses of Arctic Tundra to Experimental and Observed Changes in Climate, Ecology, 76, 694-711, 1995.

Chen, W. J., Zhang, Y., Cihlar, J., Smith, S. L., and Riseborough, D. W.: Changes in soil temperature and active layer thickness during the twentieth century in a region in western Canada, J. Geophys. Res.-Atmos., 108, 4696, doi:10.1029/2002jd003355, 2003.

Clark, P. U., Pisias, N. G., Stocker, T. F., and Weaver, A. J.: The role of the thermohaline circulation in abrupt climate change, Nature, 415, 863-869, 2002.

Comiso, J. C. and Parkinson, C. L.: Satellite-Observed Changes in the Arctic, Physics Today, 57, 38-44, 2004.

Copeland, N., Cape, J. N., and Heal, M. R.: Volatile organic compound emissions from Miscanthus and short rotation coppice willow bioenergy crops, Atmos. Environ., 60, 327-335, doi:10.1016/j.atmosenv.2012.06.065, 2012.

Crutzen, P. J. and Zimmermann, P. H.: The Changing Photochemistry of the Troposphere, Tellus A, 43, 136-151, 1991.

Di Liberto, L., Angelini, F., Pietroni, I., Cairo, F., Donfrancesco, G. D., Viola, A., Argentini, S., Fierli, F., Gobbi, G., Maturilli, 
M., Neuber, R., and Snels, M.: Estimate of the Arctic Convective Boundary Layer Height from Lidar Observations: A Case Study, Adv. Meteorol., 2012, 851927, doi:10.1155/2012/851927, 2012.

Ekberg, A., Arneth, A., Hakola, H., Hayward, S., and Holst, T.: Isoprene emission from wetland sedges, Biogeosciences, 6, 601613, doi:10.5194/bg-6-601-2009, 2009.

Ekberg, A., Arneth, A., and Holst, T.: Isoprene emission from Sphagnum species occupying different growth positions above the water table, Boreal. Environ. Res., 16, 47-59, 2011.

Elmendorf, S. C., Henry, G. H. R., Hollister, R. D., Bjork, R. G., Boulanger-Lapointe, N., Cooper, E. J., Cornelissen, J. H. C., Day, T. A., Dorrepaal, E., Elumeeva, T. G., Gill, M., Gould, W. A., Harte, J., Hik, D. S., Hofgaard, A., Johnson, D. R., Johnstone, J. F., Jonsdottir, I. S., Jorgenson, J. C., Klanderud, K., Klein, J. A., Koh, S., Kudo, G., Lara, M., Levesque, E., Magnusson, B., May, J. L., Mercado-Diaz, J. A., Michelsen, A., Molau, U., Myers-Smith, I. H., Oberbauer, S. F., Onipchenko, V. G., Rixen, C., Martin Schmidt, N., Shaver, G. R., Spasojevic, M. J., orhallsdottir, o. E., Tolvanen, A., Troxler, T., Tweedie, C. E., Villareal, S., Wahren, C.-H., Walker, X., Webber, P. J., Welker, J. M., and Wipf, S.: Plot-scale evidence of tundra vegetation change and links to recent summer warming, Nature Clim. Change, 2, $453-$ 457, 2012

Euskirchen, E. S., Bret-Harte, M. S., Scott, G. J., Edgar, C., and Shaver, G. R.: Seasonal patterns of carbon dioxide and water fluxes in three representative tundra ecosystems in northern Alaska, Ecosphere, 3, 4, doi:10.1890/es11-00202.1, 2012.

Fall, R.: Abundant oxygenates in the atmosphere: A biochemical perspective, Chem. Rev., 103, 4941-4951, doi:10.1021/Cr0206521, 2003.

Faubert, P., Tiiva, P., Rinnan, A., Michelsen, A., Holopainen, J. K., and Rinnan, R.: Doubled volatile organic compound emissions from subarctic tundra under simulated climate warming, New Phytol., 187, 199-208, doi:10.1111/j.1469-8137.2010.03270.x, 2010.

Faubert, P., Tiiva, P., Michelsen, A., Rinnan, Å., Ro-Poulsen, H., and Rinnan, R.: The shift in plant species composition in a subarctic mountain birch forest floor due to climate change would modify the biogenic volatile organic compound emission profile, Plant. Soil, 352, 199-215, doi:10.1007/s11104-011-0989-2, 2012

Figueroa, J. A., Cabrera, H. M., Queirolo, C., and Hinojosa, L. F.: Variability of water relations and photosynthesis in Eucryphia cordifolia Cav. (Cunoniaceae) over the range of its latitudinal and altitudinal distribution in Chile, Tree. Physiol., 30, 574-585, doi:10.1093/treephys/tpq016, 2010.

Forbes, B. C., Fauria, M. M., and Zetterberg, P.: Russian Arctic warming and "greening" are closely tracked by tundra shrub willows, Glob. Change Biol., 16, 1542-1554, doi:10.1111/j.13652486.2009.02047.x, 2010.

Frauenfeld, O. W., Zhang, T. J., Barry, R. G., and Gilichinsky, D.: Interdecadal changes in seasonal freeze and thaw depths in Russia, J. Geophys. Res.-Atmos., 109, D05101, doi:10.1029/2003jd004245, 2004.

Fuentes, J. D., Lerdau, M., Atkinson, R., Baldocchi, D., Bottenheim, J. W., Ciccioli, P., Lamb, B., Geron, C., Gu, L., Guenther, A., Sharkey, T. D., and Stockwell, W.: Biogenic hydrocarbons in the atmospheric boundary layer: A review, B. Am. Meteorol. Soc., 81, 1537-1575, 2000.
Geron, C., Guenther, A., Greenberg, J., Loescher, H. W., Clark, D., and Baker, B.: Biogenic volatile organic compound emissions from a lowland tropical wet forest in Costa Rica, Atmos. Environ., 36, 3793-3802, 2002.

Geron, C., Guenther, A., Greenberg, J., Karl, T., and Rasmussen, R.: Biogenic volatile organic compound emissions from desert vegetation of the southwestern US, Atmos. Environ., 40, 16451660, doi:10.1016/j.atmosenv.2005.11.011, 2006.

Goldstein, A. H., Daube, B. C., Munger, J. W., and Wofsy, S. C.: Automated in-Situ Monitoring of Atmospheric Nonmethane Hydrocarbon Concentrations and Gradients, J. Atmos. Chem., 21, 43-59, 1995.

Gough, L. and Hobbie, S. E.: Responses of moist non-acidic arctic tundra to altered environment: productivity, biomass, and species richness, Oikos, 103, 204-216, 2003.

Goulden, M. L., Munger, J. W., Fan, S.-M., Daube, B. C., and Wofsy, S. C.: Measurements of carbon sequestration by longterm eddy covariance: methods and a critical evaluation of accuracy, Glob. Change Biol., 2, 169-182, doi:10.1111/j.13652486.1996.tb00070.x, 1996.

Gregory, G. L., Anderson, B. E., Warren, L. S., Browell, E. V., Bagwell, D. R., and Hudgins, C. H.: Tropospheric Ozone and Aerosol Observations: The Alaskan Arctic, J. Geophys. Res., 97, 16451-16471, doi:10.1029/91jd01310, 1992.

Grote, R. and Niinemets, U.: Modeling volatile isoprenoid emissions - a story with split ends, Plant. Biology., 10, 8-28, doi:10.1055/s-2007-964975, 2008.

Guenther, A. B. and Hills, A. J.: Eddy covariance measurement of isoprene fluxes, J. Geophys. Res.-Atmos., 103, 13145-13152, 1998.

Guenther, A. B., Zimmerman, P. R., Harley, P. C., Monson, R. K., and Fall, R.: Isoprene and Monoterpene Emission Rate Variability - Model Evaluations and Sensitivity Analyses, J. Geophys. Res.-Atmos., 98, 12609-12617, 1993.

Guenther, A., Otter, L., Zimmerman, P., Greenberg, J., Scholes, R., and Scholes, M.: Biogenic hydrocarbon emissions from southern African savannas, J. Geophys. Res.-Atmos., 101, 25859-25865, 1996.

Guenther, A., Baugh, B., Brasseur, G., Greenberg, J., Harley, P., Klinger, L., Serca, D., and Vierling, L.: Isoprene emission estimates and uncertainties for the Central African EXPRESSO study domain, J. Geophys. Res.-Atmos., 104, 30625-30639, doi:10.1029/1999jd900391, 1999.

Guenther, A., Karl, T., Harley, P., Wiedinmyer, C., Palmer, P. I., and Geron, C.: Estimates of global terrestrial isoprene emissions using MEGAN (Model of Emissions of Gases and Aerosols from Nature), Atmos. Chem. Phys., 6, 3181-3210, doi:10.5194/acp-63181-2006, 2006.

Haapanala, S., Ekberg, A., Hakola, H., Tarvainen, V., Rinne, J., Hellén, H., and Arneth, A.: Mountain birch - potentially large source of sesquiterpenes into high latitude atmosphere, Biogeosciences, 6, 2709-2718, doi:10.5194/bg-6-2709-2009, 2009.

Harley, P. C., Litvak, M. E., Sharkey, T. D., and Monson, R. K.: Isoprene Emission from Velvet Bean-Leaves - Interactions among Nitrogen Availability, Growth Photon Flux-Density, and Leaf Development, Plant. Physiol., 105, 279-285, 1994.

Harley, P., Guenther, A., and Zimmerman, P.: Effects of light, temperature and canopy position on net photosynthesis and isoprene emission from sweetgum (Liquidambar styraciflua) leaves, Tree. 
Physiol., 16, 25-32, 1996.

Harrison, S. P., Morfopoulos, C., Dani, K. G. S., Prentice, I. C., Arneth, A., Atwell, B. J., Barkley, M. P., Leishman, M. R., Loreto, F., Medlyn, B. E., Niinemets, Ü., Possell, M., Peñuelas, J., and Wright, I. J.: Volatile isoprenoid emissions from plastid to planet, New Phytol., 197, 49-57, doi:10.1111/nph.12021, 2013.

Harriss, R. C., Sachse, G. W., Hill, G. F., Wade, L., Bartlett, K. B., Collins, J. E., Steele, L. P., and Novelli, P. C.: Carbon Monoxide and Methane in the North American Arctic and Subarctic Troposphere: July and August 1988, J. Geophys. Res., 97, 1658916599, doi:10.1029/91jd02037, 1992a.

Harriss, R. C., Wofsy, S. C., Bartlett, D. S., Shipham, M. C., Jacob, D. J., Hoell, J. M., Bendura, R. J., Drewry, J. W., Mcneal, R. J., Navarro, R. L., Gidge, R. N., and Rabine, V. E.: The Arctic Boundary-Layer Expedition (Able-3a) - July August 1988, J. Geophys. Res.-Atmos., 97, 16383-16394, 1992b.

Helmig, D., Oltmans, S. J., Carlson, D., Lamarque, J. F., Jones, A., Labuschagne, C., Anlauf, K., and Hayden, K.: A review of surface ozone in the polar regions, Atmos. Environ., 41, 5138-5161, doi:10.1016/j.atmosenv.2006.09.053, 2007.

Hobbie, S. E. and Chapin, F. S.: Response of tundra plant biomass, aboveground production, nitrogen, and $\mathrm{CO}_{2}$ flux to experimental warming, Ecology, 79, 1526-1544, 1998.

Holopainen, J. K. and Gershenzon, J.: Multiple stress factors and the emission of plant VOCs, Trends. Plant. Sci., 15, 176-184, doi:10.1016/j.tplants.2010.01.006, 2010.

Holst, T., Arneth, A., Hayward, S., Ekberg, A., Mastepanov, M., Jackowicz-Korczynski, M., Friborg, T., Crill, P. M., and Bäckstrand, K.: BVOC ecosystem flux measurements at a high latitude wetland site, Atmos. Chem. Phys., 10, 1617-1634, doi:10.5194/acp-10-1617-2010, 2010.

IPCC: Climate Change 2007 - The Physical Science Basis: Working Group I Contribution to the Fourth Assessment Report of the IPCC, edited by: Solomon, S., Qin, D., Manning, M., Chen, Z., Marquis, M., Averyt, K. B., Tignor, M., and Miller, H. L., Cambridge University Press, NY, USA, 2007.

Jacob, D. J., Fan, S. M., Wofsy, S. C., Spiro, P. A., Bakwin, P. S., Ritter, J. A., Browell, E. V., Gregory, G. L., Fitzjarrald, D. R., and Moore, K. E.: Deposition of Ozone to Tundra, J. Geophys. Res.-Atmos., 97, 16473-16479, 1992.

Kade, A., Bret-Harte, M. S., Euskirchen, E. S., Edgar, C., and Fulweber, R. A.: Upscaling of $\mathrm{CO}_{2}$ fluxes from heterogeneous tundra plant communities in Arctic Alaska, J. Geophys. Res.Biogeo, 117, G04007, doi:10.1029/2012jg002065, 2012.

Karl, T., Potosnak, M., Guenther, A., Clark, D., Walker, J., Herrick, J. D., and Geron, C.: Exchange processes of volatile organic compounds above a tropical rain forest: Implications for modeling tropospheric chemistry above dense vegetation, J. Geophys. Res.-Atmos., 109, D18306, doi:10.1029/2004jd004738, 2004.

Karl, M., Guenther, A., Köble, R., Leip, A., and Seufert, G.: A new European plant-specific emission inventory of biogenic volatile organic compounds for use in atmospheric transport models, Biogeosciences, 6, 1059-1087, doi:10.5194/bg-6-1059-2009, 2009.

Keller, M. and Lerdau, M.: Isoprene emission from tropical forest canopy leaves, Global. Biogeochem. Cy., 13, 19-29, 1999.

Kwok, R., Cunningham, G. F., Wensnahan, M., Rigor, I., Zwally, H. J., and Yi, D.: Thinning and volume loss of the Arctic Ocean sea ice cover: 2003-2008, J. Geophys. Res.-Oceans., 114, C07005, doi:10.1029/2009jc005312, 2009.
Langford, B., Misztal, P. K., Nemitz, E., Davison, B., Helfter, C., Pugh, T. A. M., MacKenzie, A. R., Lim, S. F., and Hewitt, C. N.: Fluxes and concentrations of volatile organic compounds from a South-East Asian tropical rainforest, Atmos. Chem. Phys., 10, 8391-8412, doi:10.5194/acp-10-8391-2010, 2010.

Laothawornkitkul, J., Taylor, J. E., Paul, N. D., and Hewitt, C. N.: Biogenic volatile organic compounds in the Earth system, New Phytologist, 183, 27-51, doi:10.1111/j.14698137.2009.02859.x, 2009.

Lathiere, J., Hewitt, C. N., and Beerling, D. J.: Sensitivity of isoprene emissions from the terrestrial biosphere to 20th century changes in atmospheric $\mathrm{CO}_{2}$ concentration, climate, and land use, Global. Biogeochem. Cy., 24, GB1004, doi:10.1029/2009gb003548, 2010.

Loreto, F., Mannozzi, M., Maris, C., Nascetti, P., Ferranti, F., and Pasqualini, S.: Ozone quenching properties of isoprene and its antioxidant role in leaves, Plant. Physiol., 126, 993-1000, 2001.

Ma, J., Hung, H., Tian, C., and Kallenborn, R.: Revolatilization of persistent organic pollutants in the Arctic induced by climate change, Nature Clim. Change, 1, 255-260, 2011.

Macias-Fauria, M., Forbes, B. C., Zetterberg, P., and Kumpula, T.: Eurasian Arctic greening reveals teleconnections and the potential for structurally novel ecosystems, Nature Clim. Change, 2, 613-618, doi:10.1038/nclimate1558, 2012.

McCormick, A. C., Unsicker, S. B., and Gershenzon, J.: The specificity of herbivore-induced plant volatiles in attracting herbivore enemies, Trends. Plant. Sci., 17, 303-310, doi:10.1016/j.tplants.2012.03.012, 2012.

McKinney, K. A., Lee, B. H., Vasta, A., Pho, T. V., and Munger, J. W.: Emissions of isoprenoids and oxygenated biogenic volatile organic compounds from a New England mixed forest, Atmos. Chem. Phys., 11, 4807-4831, doi:10.5194/acp-11-4807-2011, 2011.

Monson, R. K. and Fall, R.: Isoprene Emission from Aspen Leaves - Influence of Environment and Relation to Photosynthesis and Photorespiration, Plant. Physiol., 90, 267-274, 1989.

Monson, R. K., Trahan, N., Rosenstiel, T. N., Veres, P., Moore, D., Wilkinson, M., Norby, R. J., Volder, A., Tjoelker, M. G., Briske, D. D., Karnosky, D. F., and Fall, R.: Isoprene emission from terrestrial ecosystems in response to global change: minding the gap between models and observations, Philos. T. R. Soc. A, 365, 1677-1695, doi:10.1098/rsta.2007.2038, 2007.

Monson, R. K., Grote, R., Niinemets, U., and Schnitzler, J. P.: Modeling the isoprene emission rate from leaves, New Phytol., 195, 541-559, doi:10.1111/j.1469-8137.2012.04204.x, 2012.

Myneni, R. B., Keeling, C. D., Tucker, C. J., Asrar, G., and Nemani, R. R.: Increased plant growth in the northern high latitudes from 1981 to 1991, Nature, 386, 698-702, 1997.

Nay, S. M., Mattson, K. G., and Bormann, B. T.: Biases of Chamber Methods for Measuring Soil $\mathrm{CO}_{2}$ Efflux Demonstrated with a Laboratory Apparatus, Ecology, 75, 2460-2463, 1994.

Niinemets, U.: Mild versus severe stress and BVOCs: thresholds, priming and consequences, Trends. Plant. Sci., 15, 145-153, doi:10.1016/j.tplants.2009.11.008, 2010.

O’Dowd, C. D., Aalto, P., Hameri, K., Kulmala, M., and Hoffmann, T.: Aerosol formation - Atmospheric particles from organic vapours, Nature, 416, 497-498, 2002.

Olofsson, M., Ek-Olausson, B., Jensen, N. O., Langer, S., and Ljungstrom, E.: The flux of isoprene from a willow coppice plan- 
tation and the effect on local air quality, Atmos. Environ., 39, 2061-2070, doi:10.1016/j.atmosenv.2004.12.015, 2005.

Ortega, J. and Helmig, D.: Approaches for quantifying reactive and low-volatility biogenic organic compound emissions by vegetation enclosure techniques - Part A, Chemosphere, 72, 343-364, doi:10.1016/j.chemosphere.2007.11.020, 2008.

Otter, L., Guenther, A., Wiedinmyer, C., Fleming, G., Harley, P., and Greenberg, J.: Spatial and temporal variations in biogenic volatile organic compound emissions for Africa south of the equator, J. Geophys. Res.-Atmos., 108, 8505, doi:10.1029/2002jd002609, 2003.

Overpeck, J., Hughen, K., Hardy, D., Bradley, R., Case, R., Douglas, M., Finney, B., Gajewski, K., Jacoby, G., Jennings, A., Lamoureux, S., Lasca, A., MacDonald, G., Moore, J., Retelle, M., Smith, S., Wolfe, A., and Zielinski, G.: Arctic environmental change of the last four centuries, Science, 278, 1251-1256, 1997.

Papiez, M. R., Potosnak, M. J., Goliff, W. S., Guenther, A. B., Matsunaga, S. N., and Stockwell, W. R.: The impacts of reactive terpene emissions from plants on air quality in Las Vegas, Nevada, Atmos. Environ., 43, 4109-4123, doi:10.1016/j.atmosenv.2009.05.048, 2009.

Peñuelas, J., and Llusià, J.: BVOCs: plant defense against climate warming?, Trends. Plant. Sci., 8, 105-109, doi:10.1016/s13601385(03)00008-6, 2003.

Peñuelas, J. and Staudt, M.: BVOCs and global change, Trends Plant Sci, 15, 133-144, doi:10.1016/j.tplants.2009.12.005, 2010.

Petron, G., Harley, P., Greenberg, J., and Guenther, A.: Seasonal temperature variations influence isoprene emission, Geophys. Res. Lett., 28, 1707-1710, 2001.

Pinto, D. M., Blande, J. D., Souza, S. R., Nerg, A. M., and Holopainen, J. K.: Plant Volatile Organic Compounds (VOCs) in Ozone (O-3) Polluted Atmospheres: The Ecological Effects, J. Chem. Ecol., 36, 22-34, doi:10.1007/s10886-009-9732-3, 2010.

Pressley, S., Lamb, B., Westberg, H., Flaherty, J., Chen, J., and Vogel, C.: Long-term isoprene flux measurements above a northern hardwood forest, J. Geophys. Res.-Atmos., 110, D07301, doi:10.1029/2004jd005523, 2005.

Rasmussen, R. A. and Khalil, M. A. K.: Atmospheric benzene and toluene, Geophys. Res. Lett., 10, 1096-1099, doi:10.1029/GL010i011p01096, 1983.

Rastetter, E. B., Williams, M., Griffin, K. L., Kwiatkowski, B. L., Tomasky, G., Potosnak, M. J., Stoy, P. C., Shaver, G. R., Stieglitz, M., Hobbie, J. E., and Kling, G. W.: Processing arctic eddy-flux data using a simple carbon-exchange model embedded in the ensemble Kalman filter, Ecol. Appl., 20, 1285-1301, 2010.

Rawlins, M. A., Steele, M., Holland, M. M., Adam, J. C., Cherry, J. E., Francis, J. A., Groisman, P. Y., Hinzman, L. D., Huntington, T. G., Kane, D. L., Kimball, J. S., Kwok, R., Lammers, R. B., Lee, C. M., Lettenmaier, D. P., McDonald, K. C., Podest, E., Pundsack, J. W., Rudels, B., and Serreze, M. C.: Analysis of the Arctic System for Freshwater Cycle Intensification: Observations and Expectations, J. Clim., 23, 5715-5737, doi:10.1175/2010jcli3421.1, 2010.

Rinnan, R., Rinnan, A., Faubert, P., Tiiva, P., Holopainen, J. K., and Michelsen, A.: Few long-term effects of simulated climate change on volatile organic compound emissions and leaf chemistry of three subarctic dwarf shrubs, Environ. Exp. Bot., 72, 377-386, doi:10.1016/j.envexpbot.2010.11.006, 2011.
Rinne, J., Hakola, H., Laurila, T., and Rannik, U.: Canopy scale monoterpene emissions of Pinus sylvestris dominated forests, Atmos. Environ., 34, 1099-1107, 2000.

Rinne, H. J. I., Guenther, A. B., Greenberg, J. P., and Harley, P. C.: Isoprene and monoterpene fluxes measured above Amazonian rainforest and their dependence on light and temperature, Atmos. Environ., 36, 2421-2426, 2002.

Rosenstiel, T. N., Ebbets, A. L., Khatri, W. C., Fall, R., and Monson, R. K.: Induction of poplar leaf nitrate reductase: A test of extrachloroplastic control of isoprene emission rate, Plant. Biology., 6, 12-21, doi:10.1055/S-2003-44722, 2004.

Sandholm, S. T., Bradshaw, J. D., Chen, G., Singh, H. B., Talbot, R. W., Gregory, G. L., Blake, D. R., Sachse, G. W., Browell, E. V., Barrick, J. D. W., Shipham, M. A., Bachmeier, A. S., and Owen, D.: Summertime Tropospheric Observations Related to $\mathrm{N}_{\mathrm{x}} \mathrm{O}_{\mathrm{y}}$ Distributions and Partitioning Over Alaska: Arctic Boundary Layer Expedition 3A, J. Geophys. Res., 97, 16481-16509, doi:10.1029/92jd01491, 1992.

Serreze, M. C., Walsh, J. E., Chapin, F. S., Osterkamp, T., Dyurgerov, M., Romanovsky, V., Oechel, W. C., Morison, J., Zhang, T., and Barry, R. G.: Observational evidence of recent change in the northern high-latitude environment, Clim. Change, 46, 159-207, 2000.

Sharkey, T. D. and Singsaas, E. L.: Why Plants Emit Isoprene, Nature, 374, 769-769, 1995.

Sharkey, T. D. and Yeh, S. S.: Isoprene emission from plants, Annu. Rev. Plant. Phys., 52, 407-436, 2001.

Sharkey, T. D., Singsaas, E. L., Lerdau, M. T., and Geron, C. D.: Weather effects on isoprene emission capacity and applications in emissions algorithms, Ecol. Appl., 9, 1132-1137, 1999.

Sharkey, T. D., Wiberley, A. E., and Donohue, A. R.: Isoprene emission from plants: Why and how, Ann. Bot.-London, 101, 5-18, doi:10.1093/Aob/Mcm240, 2008.

Shaver, G. R., Bret-Harte, S. M., Jones, M. H., Johnstone, J., Gough, L., Laundre, J., and Chapin, F. S.: Species composition interacts with fertilizer to control long-term change in tundra productivity, Ecology, 82, 3163-3181, 2001.

Singh, H. B., O'Hara, D., Herlth, D., Bradshaw, J. D., Sandholm, S. T., Gregory, G. L., Sachse, G. W., Blake, D. R., Crutzen, P. J., and Kanakidou, M. A.: Atmospheric Measurements of Peroxyacetyl Nitrate and other Organic Nitrates at High Latitudes: Possible Sources and Sinks, J. Geophys. Res., 97, 16511-16522, doi:10.1029/91jd00889, 1992.

Spirig, C., Guenther, A., Greenberg, J. P., Calanca, P., and Tarvainen, $\mathrm{V}$.: Tethered balloon measurements of biogenic volatile organic compounds at a Boreal forest site, Atmos. Chem. Phys., 4, 215-229, doi:10.5194/acp-4-215-2004, 2004.

Stockwell, W. R. and Goliff, W. S.: Measurement of actinic flux and the calculation of photolysis rate parameters for the Central California Ozone Study, Atmos. Environ., 38, 5169-5177, doi:10.1016/j.atmosenv.2004.05.048, 2004.

Sturm, M., McFadden, J. P., Liston, G. E., Chapin, F. S., Racine, C. H., and Holmgren, J.: Snow-shrub interactions in Arctic tundra: A hypothesis with climatic implications, J. Clim., 14, 336-344, 2001.

Sumner, A. L. and Shepson, P. B.: Snowpack production of formaldehyde and its effect on the Arctic troposphere, Nature, 398, 230-233, 1999. 
Sumner, A. L., Shepson, P. B., Grannas, A. M., Bottenheim, J. W., Anlauf, K. G., Worthy, D., Schroeder, W. H., Steffen, A., Domine, F., Perrier, S., and Houdier, S.: Atmospheric chemistry of formaldehyde in the Arctic troposphere at Polar Sunrise, and the influence of the snowpack, Atmos. Environ., 36, 2553-2562, 2002.

Talbot, R. W., Vijgen, A. S., and Harriss, R. C.: Soluble Species in the Arctic Summer Troposphere: Acidic Gases, Aerosols, and Precipitation, J. Geophys. Res., 97, 16531-16543, doi:10.1029/91jd00118, 1992.

Tape, K., Sturm, M., and Racine, C.: The evidence for shrub expansion in Northern Alaska and the Pan-Arctic, Glob. Change Biol., 12, 686-702, doi:10.1111/j.1365-2486.2006.01128.x, 2006.

Tarvainen, V., Hakola, H., Rinne, J., Hellen, H., and Haapanala, S.: Towards a comprehensive emission inventory of terpenoids from boreal ecosystems, Tellus B, 59, 526-534, doi:10.1111/j.16000889.2007.00263.x, 2007.

Tiiva, P., Rinnan, R., Faubert, P., Rasanen, J., Holopainen, T., Kyro, E., and Holopainen, J. K.: Isoprene emission from a subarctic peatland under enhanced UV-B radiation, New Phytol., 176, 346-355, doi:10.1111/j.1469-8137.2007.02164.x, 2007.

Tiiva, P., Faubert, P., Michelsen, A., Holopainen, T., Holopainen, J. K., and Rinnan, R.: Climatic warming increases isoprene emission from a subarctic heath, New Phytol., 180, 853-863, doi:10.1111/j.1469-8137.2008.02587.x, 2008.

Tiiva, P., Faubert, P., Raty, S., Holopainen, J. K., Holopainen, T., and Rinnan, R.: Contribution of vegetation and water table on isoprene emission from boreal peatland microcosms, Atmos. Environ., 43, 5469-5475, doi:10.1016/j.atmosenv.2009.07.026, 2009.

Trapp, S. and Croteau, R.: Defensive resin biosynthesis in conifers, Annu. Rev. Plant. Phys., 52, 689-724, 2001.

Turnipseed, A. A., Anderson, D. E., Blanken, P. D., Baugh, W. M., and Monson, R. K.: Airflows and turbulent flux measurements in mountainous terrain Part 1, Agr. Forest Meteorol., 119, 1-21, doi:10.1016/S0168-1923(03)00136-9, 2003. van Wijk, M. T., Clemmensen, K. E., Shaver, G. R., Williams, M., Callaghan, T. V., Chapin, F. S., Cornelissen, J. H. C., Gough, L., Hobbie, S. E., Jonasson, S., Lee, J. A., Michelsen, A., Press, M. C., Richardson, S. J., and Rueth, H.: Long-term ecosystem level experiments at Toolik Lake, Alaska, and at Abisko, Northern Sweden: generalizations and differences in ecosystem and plant type responses to global change, Glob. Change Biol., 10, 105-123, 2004.

Walker, M. D., Walker, D. A., Welker, J. M., Arft, A. M., Bardsley, T., Brooks, P. D., Fahnestock, J. T., Jones, M. H., Losleben, M., Parsons, A. N., Seastedt, T. R., and Turner, P. L.: Long-term experimental manipulation of winter snow regime and summer temperature in arctic and alpine tundra, Hydrol. Process., 13, 2315-2330, 1999.

Webb, E. K., Pearman, G. I., and Leuning, R.: Correction of flux measurements for density effects due to heat and water vapour transfer, Q. J. Roy. Meteorol. Soc., 106, 85-100, doi:10.1002/qj.49710644707, 1980.

Wiedinmyer, C., Guenther, A., Harley, P., Hewitt, C.N., Geron, C., Artaxo, P., Steinbrecher, R., Rasmussen: Global organic emissions from vegetation, in: Emissions Of Atmospheric Trace Compounds, edited by: Granier, C., Artaxo, P. E., and Reeves, C. E., Kluwer Academic Publishers, Dordrecht, The Netherlands, 115-170, 2004.

Wilczak, J. M., Oncley, S. P., and Stage, S. A.: Sonic anemometer tilt correction algorithms, Bound.-Lay. Meteorol., 99, 127-150, 2001.

Williams, M., Street, L. E., van Wijk, M. T., and Shaver, G. R.: Identifying differences in carbon exchange among arctic ecosystem types, Ecosystems, 9, 288-304, doi:10.1007/s10021-005-0146y, 2006.

Wilson, J. W.: Observations on the Temperatures of Arctic Plants and Their Environment, J. Ecol., 45, 499-531, doi:10.2307/2256933, 1957.

Yuan, J. S., Himanen, S. J., Holopainen, J. K., Chen, F., and Stewart, C. N.: Smelling global climate change: mitigation of function for plant volatile organic compounds, Trends in ecology and evolution (Personal edition), 24, 323-331, 2009. 